\title{
Does an Asset Owner's Institutional Setting Influence Its Decision to Sign the Principles for Responsible Investment?
}

\author{
Andreas G. F. Hoepner ${ }^{1,2,3}$ (I) $\cdot$ Arleta A. A. Majoch ${ }^{4} \cdot$ Xiao Y. Zhou $^{5}$
}

Received: 20 March 2017 / Accepted: 22 May 2019 / Published online: 6 June 2019

(c) The Author(s) 2019

\begin{abstract}
From a simple idea to unite asset owners in their quest for responsible investment (RI) at its launch in April 2006, the United Nations supported Principles for Responsible Investment (PRI) have grown in just one decade into an initiative with more than 1500 fee-paying signatories. Jointly, the PRI's signatories hold assets worth more than $\$ 80$ trillion, making it one of the more prevalent not-for-profit organizations worldwide. Furthermore, the PRI's ambitious mission to transform the financial system at large into a more sustainable one makes it a worthwhile subject of inquiry from an institutional perspective. We undertake an empirical investigation of the adoption of the PRI by asset owners during five crucial years of the association's emergence: 2007-2011. Following a tripartite view of institutional theory proposed by Scott (Institutions and organizations. Foundations for organizational science, A Sage Publication Series, London, 1995), we explore if regulative, normative, and cultural-cognitive factors influence an asset owner's decision to subscribe to the PRI. Applying both parametric and nonparametric survival analysis, we find that asset owners are indeed significantly affected by normative, cultural-cognitive, and regulative aspects. In particular, (i) public service employee and labor union pension funds (ii) from social backgrounds more culturally aligned with values represented by the RI movement (iii) with historically more voluntary legislation on environmental, social, and governance (ESG) issues are most likely to sign the PRI. In contrast, institutional environments with a higher number of pre-existing mandatory ESG regulation decrease the likelihood of signing the PRI. Our results indicate that normative and cultural-cognitive factors were crucial contributors to the PRI's growth. With respect to the regulative environments, our results imply that some asset owners may use the PRI as a collective industry initiative to substitute for mandatory legislation. Conversely, a high level of historical mandatory legislation may constrain organizational resources that could otherwise be dedicated to voluntary initiatives such as PRI. Our findings are robust to relevant controls and econometric concerns.
\end{abstract}

Keywords Institutional theory $\cdot$ Asset owners $\cdot$ Pension funds $\cdot$ Principles for responsible investment (PRI)

Xiao Y. Zhou

xiao.zhou@smithschool.ox.ac.uk

Andreas G. F. Hoepner

andreas.hoepner@ucd.ie

Arleta A. A. Majoch

arleta.majoch@aurielequities.com

1 Smurfit Graduate Business School, University College Dublin, Carysfort Avenue, Blackrock, Co. Dublin A94 XF34, Republic of Ireland

2 Stockholm School of Economics, Mistra Financial Systems (MFS), Box 6501, 11383 Stockholm, Sweden

3 Technical Expert Group on Sustainable Finance, DG FISMA, European Commission, Brussels, Belgium

4 Auriel Equities, Broad St, St Helier, Jersey JE2 3RR, UK

5 Smith School of Enterprise and the Environment, University of Oxford, South Parks Road, Oxford OX1 3QY, UK

\section{Introduction}

The PRI is a responsible investment (RI) initiative promoting the consideration of ESG factors by institutional investors. It is a Dutch not-for-profit organization with headquarters in London and offices around the world organized as local PRI "networks." In its first decade it has been tremendously successful in expanding its membership, and is considered the most important international RI initiative in existence (Vitols 2011). The PRI is aimed primarily at asset owners, who occupy the majority of its board seats (PRI 2018a, b, c). Twelve years since the initiative's launch, their recruitment into the PRI still features as one of the organization's main goals (PRI 2017 Annual Report, p. 27). However, at the point of writing this paper, asset owners account for only 
$20 \%$ of the signatory body, with PRI's own estimated asset owner market penetration of $20 \%$ versus $85 \%$ for asset managers (PRI 2018a).) This reflects the fact that asset owners have been slower than other market players to adopt ESG considerations (Mooij 2017) despite being crucial to the success of the RI movement, and with it the PRI itself.

Asset owners are instrumental for the PRI and responsible investment in general because they make the decisions about how their enormous assets, representing on average around $34 \%$ of GDP in OECD countries, are managed (Sievänen et al. 2013a). As of 2012, pension funds alone were the largest class of investors with $\$ 33.9$ trillion of assets under management (AUM) (Létourneau 2015). They own more than a quarter of publicly listed stock globally (Clowes 2000), that is a collective $25 \%$ stake in the organizations accountable for key sustainable development issues such as environmental externalities. For example, only 100 listed companies have been the source of over $70 \%$ of greenhouse gasses emitted globally since 1988 (Carbon Disclosure Project 2017). Considering developments such as the recent introduction of state pension auto-enrolment in the UK, the weight and role of asset owners in the financial industry can only be expected to continue to grow (Vitols 2011). As owners, they are in a unique position to drive more sustainable investment and corporate practices through awarding mandates and allocating capital. Membership of the PRI demonstrates an intention to do so and provides the tools for it through access to information, working groups, and opportunities to pool resources, e.g., via collaborative engagement (Dimson et al. 2018). With little over a decade left to work towards the United Nations Sustainable Development Goals (UN SDGs) and progress being too slow so far (UN 2018), the question why asset owners join the PRI becomes an especially timely and salient one.

The first attempt to formally investigate the drivers of RI adoption by asset owners was made by Majoch et al. (2016) in a content analysis paper looking at the internal motivation of asset managers and asset owners to sign the PRI from a stakeholder salience perspective. Their study had the benefit of access to a qualitative self-reported dataset making it exceptionally well positioned to analyze motivations from within an organization. In our paper, we use public, country level data available for both signatories and non-signatories that allow us to complement this internal picture with a better understanding of the contribution of the institutional setting over the same time period. We choose to structure our analysis using institutional theory, which has provided a framework for much of the academic investigation of corporate social responsibility (CSR) and responsible investment to this date (Bengtsson 2008b; Campbell 2007; Marquis et al. 2007; Moon and Vogel 2008; Matten and Moon 2008; Sandberg et al. 2009).
As we are building on the Majoch et al. study, we adopt the same sample period of the first 5 years of the PRI's existence, when PRI membership did neither involve a membership fee nor a reporting burden and the growth rate in both asset owner and overall signatory numbers was the highest, with none of the consecutive years since matching it or indeed even exceeding 20\% year on year (PRI 2018a, b, c). ${ }^{1}$ By investigating the question of why asset owners signed the PRI in these initial years, we intend to shed light on the drivers of the PRI's strong early growth. This may help equivalent organizations to learn from the PRI's success and could also support the PRI itself to recreate its asset owner growth, which is among the PRI's very explicitly stated goals as documented in its recent annual reports. Both developments would ultimately help drive the investment industry to contribute more to the achievement of the UN SDGs.

In structuring our analysis, we follow Scott (1995), who organizes much of the broad theoretical thinking about institutions into a framework of three pillars: the regulative, normative, and cultural-cognitive. We apply public data as proxies for each of these pillars and analyze the importance of each of them over a 5-year sample period between 2007 and 2011, for a group of asset owner signatories and nonsignatories. More specifically, we employ survival analysis, which utilizes information content from both the decision to sign the PRI as well as the time it took to do so.

\section{Literature Review}

In 2006, the year the UN PRI was launched, Waddock wrote about the various voluntary initiatives at the center of the responsible investment movement as an emerging voluntary responsibility assurance system, most commonly referred to in the literature as private regulation (Campbell 2007; Vogel 2010). Waddock lists the UN PRI, with it at the time $\$ 6.5$ trillion of signatory AUM, as part of this emerging institutional infrastructure designed specifically to hold institutional investors more accountable, responsible, and transparent (Waddock 2008).

Since the publication of Waddock's article, the PRI has celebrated its ten-year anniversary and grown its signatory

\footnotetext{
1 Towards the end of 2011, two additional factors come into play that we believe would have had significant influence on the decision making around joining the PRI: (i) the introduction of mandatory signatory fees proportionate to investor AUM (enforced starting winter 2011/2012). (ii) An overhaul of the PRI Reporting and Assessment framework, which was made mandatory starting 2012. Both factors increased the mandatory financial and reporting burden on signatories (PRI 2017). These considerations along with the growth rates of the PRI in its initial years together motivate our choice of the sample period in this paper.
} 
AUM by an additional $\$ 70$ trillion (PRI 2018a, b, c). It has been argued to be a greenwash lacking any firm moral foundation (Eccles 2010), and also to be a positive force by facilitating the adoption of RI by institutional investors (Sievänen et al. 2013b). Surprisingly, the PRI has attracted limited academic attention compared to other sustainability initiatives such as the extensively researched UNGC (Cetindamar 2007; Janney et al. 2009; Kell 2013; Knudsen 2011; Rasche 2009; A. Rasche and Waddock 2014; Voegtlin and Pless 2014; Williams 2004) despite its rapid rise to the dominant position in the RI industry. This paper makes one step towards remedying the PRI's under-researched status and, at the same time, constitutes another contribution to the rich academic literature on institutional responsible investment.

What makes the PRI especially relevant in the context of asset owner behavior is that, besides being a general investor association, the PRI itself emphasizes its focus on asset owners as the drivers of RI in the broader financial markets, and the source of a 'multiplier effect' for responsible investment (PRI Association 2016a, b). The PRI shares this focus with not only the present paper but also many other academics analyzing and commentating the development of RI. Asset owners, as probably the most influential type of institutional investor, have inspired many academic studies on the adoption and implementation of RI. Researchers are interested in what drives this type of investor specifically to employ RI strategies (Sievänen et al. 2013a), what differentiates those that adopt them from the ones that do not (Juravle and Lewis 2008; Sievänen 2014), and what the consequences are from a performance and other perspectives (Hoepner and Schopohl 2018a, b; Renneboog et al. 2008).

\section{Asset Owners as Drivers of the RI Market}

The unique position of asset owners in the economy as institutions controlling an increasing portion of capital while acting as fiduciary to a beneficiary body routinely large enough to be representative of all of society has been mentioned earlier in this paper as the motivation for its focus on this type of institutional investor. Universal owner hypothesis proposes that the largest institutional investors are de facto invested in the market as a whole and so their portfolio will benefit more from a stable and growing overall economy than from one stock outperforming another by taking advantage of externalities such as environmental damage or destructive impact on communities (Hawley and Williams 2000, 2007; Monks 2001).

In line with this logic, researchers have argued that the universal owner perspective marks large asset owners as investors that have a lot to benefit from considering ESG factors (Kiernan 2007; Lydenberg 2007; Thamotheram and Wildsmith 2006). Gjessing and Syse (2007) take
Norway's Government Pension Fund Global, a sovereign wealth fund with close to $\$ 900$ billion AUM, as an example of an asset owner who recognizes the importance of sustainable investing to the ultimate diversified portfolio they hold (Stiglitz et al. 2000). The Norwegian investor is also widely accepted in industry and academia as a role model in terms of RI (Eurosif 2010; Hoepner and Schopohl 2018a). Others among the globally largest asset owners such as the Swedish AP Funds, or the California Public Employees' Retirement System (CalPERS) have also assumed leadership positions in incorporating ESG into their investment practices, driving demand for RI through awarding sustainability mandates to asset managers (Clark and Monk 2010; Gjessing and Syse 2007; Hawley and Williams 2007).

From the perspective of fostering a more sustainable economy, asset owners are the very top of the institutional food chain (Monks 2001). As put by Scholtens (2006), 'Finance is the grease of the economy,' controlling when and where capital is invested, as well as evaluating and monitoring the recipients of that capital. More sustainable finance would therefore mean a more sustainable economy. Busch et al. (2016) confirm that institutional investors have a key role to play in driving increased economic sustainability. As the owners of capital, asset owners are crucial for creating demand for RI, a view held widely in the industry (Eurosif 2016). Asset owners lead, and asset managers, financial intermediaries, and eventually the broader economy follow, at least in theory.

There is some empirical evidence for this effect, notably the Scholtens and Sievänen (2013) study which questions why RI and its adoption differ between countries. The researchers find that the size of the pension industry matters, a finding which supports the hypothesis of an earlier paper by Scholtens (2006) arguing the existence of a transmission mechanism between the financial system and the economy, the practical functioning of which Busch et al. (2016) question.

This characteristic of asset owners in relation to RI has been used as an argument for the importance of asset owner adoption of RI in the literature. In a widely cited paper, Sethi (2005) argues that pension funds are well positioned to encourage a more sustainable economy by engaging in responsible investment, and observes that this type of institutional investor tends to also take long-term risks (e.g., environmental) more seriously because of the nature of their commitments to beneficiaries which encourages a more beta focused investment approach rather than dynamically pursuing alpha (Clark and Knight 2011). The literature does indeed identify the pension funds that do take on responsible investment as committed and innovative adopters of RI (Cox and Schneider 2008). 


\section{Drivers of Asset Owner RI Adoption}

Academic research has explored extensively the motivation of different types of organizations to adopt corporate social responsibility (CSR) and sustainability policies with a variety of approaches, drawing upon theoretical foundations such as institutional theory (Bengtsson 2008b; Sandberg et al. 2009), stakeholder theory, or the instrumental stakeholder approach (Harjoto and Jo 2011; Hockerts and Moir 2004), and identifying motivations ranging from the purely self-interested, instrumental, to the relational, and moral (Aguilera et al. 2007; Baron 2009; Brickson 2007).

Focusing more on external economic factors, researchers such as Mackey et al. (2007) and Barnett (2007) have taken a market-based view, explaining the adoption of CSR with market, and supply and demand drivers. Others draw attention to regulation and tax incentives (Gond et al. 2011; Juravle and Lewis 2009; Scholtens 2005). However, in Campbell's influential 2007 paper, he joins other institutional theorists in arguing that economic drivers alone are insufficient to explain sustainability-related organizational behaviors (Campbell 2007; Marquis et al. 2007; Moon and Vogel 2008; Matten and Moon 2008). In this study, he develops an institutional theory of corporate responsibility, identifying specific institutional conditions under which organizations are likely to pursue social responsibility.

Moral and value-driven considerations are explored widely in the literature on the adoption of sustainability practices, both as observed at country level (Bengtsson 2008a; Scholtens and Sievänen 2013) and intra-organizational at the level of individuals shaping organizations (Cheah et al. 2011; Francoeur et al. 2017; Hemingway and Maclagan 2004). We draw on some of the country level literature in particular, as we look at the normative and cognitive aspects of institutional settings in this study.

In addition to this broader, well-developed literature, a much smaller number of studies have focused explicitly on the determinants of asset owner ESG practices. They have taken a variety of approaches and advanced our understanding of this phenomenon, although as pointed out by Sievänen (2014) the academic community is far from a consensus on why institutional investors, and asset owners, do or do not adopt RI. In a recent empirical study, Létourneau (2015) compared the ESG practices of 158 public asset owners from 47 countries and finds evidence of the significance of many country level characteristics such as population size and national wealth, and of the impact of the institutional context. The importance of country-specific factors and the institutional environment has often been underlined in studies addressing RI adoption by pension funds (Bengtsson 2008a, b; Cox and Schneider 2008; Sandberg et al. 2009; Scholtens and Dam 2007). A notable example is the recent Sievänen et al. (2013a, b) study on the drivers of responsible investment among European pension funds, using a survey of 281 institutions across 15 European countries. The study identifies several characteristics correlated with a higher likelihood of a pension fund adopting an ESG approach, including legal origin of headquarter country, ownership, and fund size. Sievänen and her co-authors recognize the need for further research on the dynamic aspect of pension fund ESG adoption, which our study undertakes with the examination of 5 years of PRI membership data.

Two papers by Juravle and Lewis (2008) and Sievänen (2014) also approach the adoption of RI by pension funds from the opposite direction, investigating the impediments to implementing RI policies. While the first identifies uncertainty around the financial consequences of ESG, fiduciary duty, and the agency problem, the latter focuses rather on the persisting confusion around, and lack of accepted guidelines for, the implementation of responsible investment.

The already large and diverse but constantly growing body of academic work on the drivers and impediments of sustainability-related practices by organizations, be it corporations or investors, are testament to the vital role these organizations have to play in the transition towards a more sustainable global society. As noted by Bernhagen and Mitchell (2010) in their paper on the determinants of corporate membership of the UNGC, non-state actors are increasingly taking over the capacity for dealing with challenges like climate change and globalization, and it is our role as researchers to pursue this process as a subject of academic enquiry. These researchers also stand behind a series of papers attempting to explain the drivers of organizational commitment to the UN Global Compact (UNGC) (Bennie et al. 2007; Bernhagen and Mitchell 2010; Bernhagen et al. 2013). They recognize the often symbolic nature of these motivations and find further support for the importance of the political and institutional environment to the adoption of voluntary codes and principles.

The launch of the PRI in April 2006 marked a turning point in the adoption of sustainability practices by the investment community, rapidly lifting responsible investment from its niche status towards the mainstream, as is well illustrated by the World Resource Institute's data on numbers of US funds incorporating any ESG criteria stagnating between 50 and 200 across the country, until a sharp increase in growth since the PRI's launch, bringing the number to 500 by 2010 and 1000 most recently (World Resource Institute 2016). The European markets have followed a similar trajectory (Mollet and Ziegler 2014). Asset owners being the key influencer for the investment industry as a whole have played a part in this growth and as such warrant further empirical enquiry, complementing and extending what has already been accomplished by the authors cited in this section. The role of the institutional environment has been emphasized in many of the reviewed studies and we aim to contribute to 
this literature by applying an institutional theory approach to the previously underexplored question of the institutional drivers of asset owner subscription to the PRI.

\section{Theory and Its Application}

This paper employs an institutional theory framework as formulated by Scott (1995). In this part of the paper, we motivate our choice of framework, explain the three pillars identified by Scott (1995), and lay out how we apply them to the analysis of the institutional environment present at the time of adoption of the PRI by asset owners in the years 2007-2011.

In his work 'Institutions and Organizations,' Scott presents an exhaustive review of institutional theory, which is a stream of theoretical thinking rather than a particular singularly defined framework as observed by Scott and Christensen (1995). The unifying idea of institutional theory, however, is that organizations are rooted in, and shaped by the broader social and cultural environment in which they operate (Scott and Christensen 1995). This is precisely the departure point for our approach to investigating the question of asset owner adoption of the PRI. It is also the conclusion of a number of influential studies on the adoption of CSR and responsible investment, among them the already mentioned Campbell (2007), establishing a set of institutional conditions conducive to the adoption of CSR such as the presence of state regulation, industry self-regulation, monitoring by NGOs, or a normative environment encouraging socially responsible behavior. Matten and Moon (2008) also argue that national differences in CSR have their source in the different institutional environments, as do Aguilera and Jackson (2003).

We choose Scott's three pillars of institutions as an analytical framework for this paper based on both (i) the prior relevant literature reviewed in the previous section (Bengtsson for example employs the regulative-normative-cognitive pillars as a framework for his 2008 discussion of the history of Scandinavian SRI), and (ii) a consideration of the nature of the research question and data used. ${ }^{2}$ While stakeholder salience theory used in previous work such as Majoch et al. (2016) offers a granular framework well suited for the classification of qualitative textual data on largely internal factors influencing an organization's decision to sign PRI, the broader categories and more established concepts of Scott's three institutional pillars are a more robust and universal framework to apply to the investigation of asset owner PRI adoption from an external, institutional environment

\footnotetext{
2 We are very grateful to an anonymous reviewer for directing us towards Scott's framework.
}

perspective. Majoch et al. (2016) also study more asset manager $(58 \%)$ than asset owner (42\%) observations, while we focus purely on the latter group. While asset managers are often multinational organizations exposed to multiple institutional contexts, asset owners include a large proportion of public service organizations (public pension funds, union funds, university endowments), which operate in a single country and institutional context. Thus, we would argue that institutional theory fits more closely to our asset owner sample than Majoch et al.'s (2016) predominantly asset manager focused dataset.

Compared to stakeholder salience theory, the tripartite institutional theory view as formulated by Scott (1995) enters more directly into conversation with much of the preexisting academic literature reviewed in the previous section, especially those also addressing the role of the differences in institutional environments in the adoption of sustainability-related practices (Bengtsson 2008a, b; Cox and Schneider 2008; Sandberg et al. 2009; Scholtens and Dam 2007; Scholtens and Sievänen 2013).

While we choose to focus our hypotheses around a tripartite institutional theory framework in this paper, we are also aware of literature on the adoption of CSR and RI that points to other institutional factors such as mimetic isomorphism (DiMaggio and Powell 1983; Dumas and Louche 2011), as well as internal and organizational variables as drivers which may interact with institutional factors (McWilliams and Siegel 2001; Sievänen et al. 2013a, b). We control for a selection of these, resulting in a combination of institutional and organizational factors being taken into account in the analysis. This is in line with the methodological choice of some other studies tackling the question of RI adoption by institutional investors, notably Sievänen et al. (2013a).

In the following sections, we define each of the three pillars of Scott's tripartite institutional theory, and motivate and explain how we apply the framework to our research question. As a result, we formulate three hypotheses around the idea that regulative, normative, and cognitive institutional environment characteristics can explain the PRI's uptake across the asset owner community.

\section{Regulative Pillar}

Scott introduces the regulative pillar as a commonly underscored aspect of institutions. It manifests itself in the setting of rules, monitoring of compliance with them, and sanctioning non-compliance. This pillar spans the continuum between informal and formal mechanisms, from ostracism in response to non-compliance with informal mores being the most informal, to legal consequences of breaking mandated law being the most formal regulative mechanism.

There is little by way of coercive, prescriptive regulation with strict enforcement mechanisms in the responsible 
investment space which would fall at the most formal end of that spectrum, but over the years investigated in this paper, the emergence of responsible investment policies and guidelines across many jurisdictions allows us to use their presence and scope as a proxy for the degree to which a regulative aspect of the institutional environment is associated with the adoption of the PRI by asset owners. Authors such as Cox and Schneider (2008), Sandberg et al. (2009), Scholtens (2005), or Bengtsson (2008a) have already suggested that country-specific regulation explains the emergence of RI practices as investors anticipate or wish to pre-empt further, more binding regulation by taking voluntary action, as if to signal to the regulator that the finance industry is regulating itself voluntarily to become more responsible and does not need policymakers to impose their own understanding of responsibility on it.

There is an additional specific aspect to the regulative pillar in this context which further motivates its inclusion: an oft-cited impediment to asset owner adoption of RI is a persistent uncertainty as to its compliance with fiduciary duty (Juravle and Lewis 2008; Sandberg 2010, 2013). The introduction of widely agreed policy and regulation encouraging institutional responsible investment removes this impediment by implying an emerging consensus that it is not a breach of fiduciary duty to consider non-financial factors in investment decision making. An example of this in the UK for instance is the amendments to the 1995 Pensions Act made in 2000, asking pensions to report on the extent to which they take ESG considerations into account. It did not oblige pensions to consider ESG, but merely to disclose their approach, this in itself being enough to signal approval of ESG investing, and that it is not at odds with fiduciary duty in the eyes of the regulator (Sparkes 2002). Such regulation might contribute to PRI signatory growth, whereby asset owners receive implicit permission from the policymakers to publicly sign up to the flagship RI initiative. That initiative then also gives them access to RI implementation support, knowledge sharing, and joint initiatives which are helpful in entering and navigating a still early-stage and unstandardized practice of responsible investment (Sievänen 2014).

There are still few truly binding RI laws as of 2018, but we are already able to draw a distinction between the informal and the formal on Scott's regulative continuum with regard to RI regulation. The French Energy Transition Law is a recent example of a formal regulative institutional setting, where investors are legally obliged to report on the consideration of ESG factors and their exposure to carbon risk. The lack of clearly defined enforcement mechanisms by the French regulator in the implementation decree, however, still makes it a soft law compared to traditional financial regulation (PRI 2016b).

Further down the spectrum towards informal regulative mechanisms would be governance and stewardship codes such as those formulated by the Financial Reporting Council that apply to asset owners but do not require compliance, merely lay out best practice principles. Moreover, based on the literature on self-regulation as replacing and competing with mandated law (Haigh and Hazelton 2004; Hart 2010; Vogel 2010) asset owners may behave differently in institutional settings focused around voluntary versus mandatory regulation, whereby voluntary regulation goes hand in hand with voluntary initiatives such as the PRI as both a differentiator and a way to pre-empt formal external regulation. ${ }^{3}$ We therefore formulate our first hypothesis as:

H1 The regulative aspect of the institutional setting explains asset owner adoption of the PRI.

\section{Normative Pillar}

The normative pillar in Scott's typology of institutional systems is defined as commonly held social norms and values which determine both the prescribed goals and desirable behavior, and the acceptable boundaries of those roles. The normative and regulative pillars can mutually reinforce each other, especially in the sense that normative systems define the constraints of accepted behavior via values and norms. They also confer rights and responsibilities however, and define social obligations. A good example of normative systems at play in the context of responsible investment is the public ostracism periodically directed at charities and foundations holding companies in their investment portfolios whose activities are perceived to go against their charitable or activist agenda, such as the article published in the Guardian criticizing the Gates Foundation for owning fossil fuel stocks (The Guardian 2015). There is no voluntary code of conduct or mandatory regulation that would constitute a regulative system that prohibits a not-for-profit to invest in fossil fuels while advocating climate change action. But the commonly understood social expectation of climate change advocates is that they do not reap financial profits

\footnotetext{
${ }^{3}$ It is noteworthy that regulations of sustainability disclosure at the corporate level may also affect asset owners' decisions to join the PRI. Empirical evidence indicates that the quality of disclosure is negatively associated with the cost of capital (Lambert et al. 2007; Hughes et al. 2007; Leuz and Schrand 2009). Greater disclosure attracts institutional investors and analyst coverage (Dhaliwal et al. 2011) and decreases the covariance of a firm's cash flow with the cash flows of other firms (Lambert et al. 2007), thus reducing the cost of capital. In addition, increased sustainability disclosure makes it possible for institutional investors to incorporate ESG factors in their investment decision making, which is directly related to their commitments as PRI signatories. Dhaliwal et al. (2011) find that asset owners appreciate corporate disclosure. Based on these considerations we believe the sustainability regulations affect pension funds investment strategies and their decision of joining PRI.
} 
from industries majorly contributing to climate change. It goes against what is their socially defined accepted behavior.

Therefore, our second hypothesis reads:

H2 The normative aspect of the institutional setting explains asset owner adoption of the PRI, whereby the type of ownership and the norms associated with it determines the likelihood of the plan signing the PRI.

\section{Cultural-Cognitive Pillar}

The cultural-cognitive pillar is defined by Scott (1995) as a common understanding and a shared logic which is perceived by individual organizations or persons as an objective and external symbolic system. These wider belief systems elicit certain behaviors because other types of behavior are inconceivable (Scott 1995). The idea of incorporating nonfinancial factors into investment decisions would arguably still have fallen within the realm of what is inconceivable in our sample years 2007-2011 to the majority of asset owners worldwide, but for example the Nordic asset owners leading the development of RI in those years and prior did so in part owing to the societal values and norms that characterize their institutional setting being aligned with the values underpinning the RI movement, such as collective responsibility and collaboration (Bengtsson 2008a).

The cultural-cognitive characteristics of the institutional setting play a role in determining the asset owner's attitude towards a new direction and set of ideas in investment practice as exemplified by the RI movement. Especially in the early days of the PRI constituting the present study's sample period when RI was still a young phenomenon, an asset owner confronted with the novel idea of incorporating non-financial, environmentally, and socially driven considerations into investment decisions did not have much policy recommendation to fall back on in deciding whether to participate in this emergent practice. Asset owners also typically act as fiduciaries of large bodies of beneficiaries from whom it is not easy to obtain explicit direction. In this situation, we hypothesize that the wider belief system the asset owner operates within helps determine their course of action. The more the new set of ideas aligned with this belief system, the more likely the institution to adopt the ideas. The weaker the alignment, the less likely an asset owner to be compelled to join the movement and in the case of responsible investment, the PRI as the initiative embodying it. Such cultural aspects feature in many studies throughout the relevant literature, including Sandberg et al. (2009) and Scholtens and Sievanen (2013), and form a consistent part of institutional theory frameworks (DiMaggio and Powell 1983; Meyer and Rowan 1977). In our analysis, we select a set of cultural characteristics that share the fundamental logic with the responsible investment movement and the
PRI, and test if their presence is positively associated with institutional membership of the PRI.

We formulate our third hypothesis as:

H3 The cultural-cognitive aspect of the institutional setting explains asset owner adoption of the PRI.

\section{Data and Method}

This section reports on how we defined our study sample, on the sources of the data used, and how it was collected and analyzed. While several of our data sources have been used before, we are to the best of our knowledge the first study to conduct a statistical analysis of the PRI adoption, since Majoch et al. (2016) conducted a content analysis only. Additionally, we are also the first study to integrate the data on environmental, social, and governance (ESG) legislation per country provided by Datamaran.

\section{Sample and Data}

The PRI asset owner signatory list was obtained directly from PRI Signatory Relations and Outreach. The PRI Reporting and Assessment survey was the source of the signatories' assets under management figures. The source of the non-signatory asset owner sample was the IPE list of the 1000 largest asset owners published annually in the September issue of the IPE magazine. For asset owner nonsignatories, the AUM data come from the P\&I Top 1000 Pension Funds list and the P\&I/Towers Watson 300 Largest Asset Owner lists. The coverage of the list has been global since 2010. The list of asset owners for years 2007-2009 has been filled in manually by the researchers, partially with the help of the P\&I/Towers Watson Top 300 Pension Funds list that has global coverage going back as far as our sample.

The resulting sample of asset owners is made up 667 organizations, among those 163 PRI signatories and 504 non-signatories as of the end of our sample period. From the period between 2007 and 2011, we document a total of 2881 observations. For PRI signatories, the observations stop at the year when an organization signed the PRI. For non-signatories, the observations conclude at the end of the sample period in 2011.

We use public data in this study to represent the regulative, normative, and cultural-cognitive institutional pillars.

\section{Regulative Pillar Proxy and Data}

For the regulative pillar, we were able to obtain aggregate statistics on the number of mandatory and voluntary legislations per country and year from Datamaran. Datamaran describes itself as "one of the world's most sophisticated 
and powerful semantic business intelligence tools." It was founded by former executives from BNP Paribas and the Global Reporting Initiative (GRI) with the ambitions to employ Artificial Intelligence (AI) technology to allow for deeper and more efficient analysis of ESG reporting. Given that any AI innovation carries risks, we requested to verify the underlying data before using the aggregated statistics per country. Our request was granted and we can confirm that the ESG legislation data per country has been accurately sourced by the data science team behind Datamaran. ${ }^{4}$ Furthermore, it is important to note that we regard ESG regulation in this study as a proxy for the regulative aspect of the institutional setting as opposed to indicating a coercive mechanism applied specifically to RI adoption by asset owners. In fact, we are not aware of a single legislation worldwide that would force asset owners to sign the PRI.

The Datamaran ESG regulations dataset contains over one thousand ESG-related regulations globally and covers 105 ESG topics ranging from Climate Change, Biodiversity, Labor Rights, and Safety, to Shareholder Activism and Board Diversity. For each regulation, the data science team clearly records the jurisdiction, commencement year, related themes, and topics, and whether it is mandatory or voluntary. Our "Appendix" shows a summary of ESG legislation data used in this study. To further test the validity of the Datamaran information, we aim to compare it with a related database. While we could not identify any other database with an equivalent number of comprehensive historical ESG legislation, we are aware of two related databases. The Carrots \& Sticks (C\&S) database ${ }^{5}$ contains about four hundred ESG-related regulations and the Food and Agriculture Organization of the United Nations (FAOLEX) aggregates purely environmentally related laws. Both can hence be seen at least as imperfect substitutes. In order to validate our ESG law data from Datamaran, we hence analyze the relationship between the total number of ESG legislations per country as displayed by Datamaran and C\&S and observe these to be positively correlated at the $1 \%$ significance level. Similarly, we compute the correlation between the environmental laws from Datamaran and FAOLEX and find them also to be positively correlated at the $1 \%$ significance level.

\footnotetext{
${ }^{4}$ Please see the following two URLs for more information on the organization and the public disclosure of the patent application underlying their AI technology: https://www.datamaran.com/about-us/, https://patentscope.wipo.int/search/en/detail.jsf?docId=WO20162032 29.

${ }^{5}$ We are very grateful to an anonymous reviewer for pointing us to this database: https://www.carrotsandsticks.net/regulations/.
}

\section{Normative Pillar Proxy and Data}

Scott explains that the indicators of the presence and strength of normative systems vary by level of analysis undertaken (Scott 1995). Normative signals would be more diffused at regional level (Europe vs. North America) and more directly observable between clearly distinguishable types of organizations with differently defined roles and acceptable behavior constraints. For the purpose of examining the institutional environment as the context for the adoption of the PRI by asset owners, we take this latter approach as the most direct and relevant available to us from a data perspective, and examine PRI adoption through the lens of ownership type. There has already been some anecdotal evidence from prior literature of the existence of a relationship between the public status of asset owners and RI adoption. For instance, Bengtsson (2008a) in his history of Scandinavian SRI from an institutional perspective emphasizes the role of the state via public pension funds, and Sievänen et al. (2013a, b) find in their survey that public pensions are more likely to adopt RI.

Juravle and Lewis (2008) point out that such a relationship can be explained by (i) the focus of public opinion on public pension plans rather than corporate pensions and (ii) the freedom of public pensions from the conflict of interest with the parent company which may prevent RI adoption by private pensions. From a normative pillar perspective, private pensions have the boundary of acceptable behavior in the form of alignment with the parent company, which public pensions are free of. It is more expected that the Swedish AP7 fund or the New York Retirement Fund divest from fossil fuels than that Exxon's corporate plan does so, or the asset managers employed by Exxon's pension plan. The different norms and expectations apply to the two types of pensions according to their ownership.

We furthermore consider labor union, church, and university pensions as separate types of ownership which we expect to be associated with the kinds of normatively prescribed goals that would encourage PRI adoption, for instance all three, universities, churches, and labor unions, are traditionally advocates of social issues (Louche et al. 2012). The Universities Superannuation Scheme in the UK is a direct example of a university pension actively practising responsible investment, along with the Church of England and the Central Finance Board of the Methodist Church carefully screening its investments in line with its ethical convictions, following in the footsteps of the church investors at the very genesis of responsible investment itself (Kreander et al. 2004; Sparkes 2002).

The PRI membership database contained a classification of pension plan ownership, which we followed for the signatory part of the sample. The researchers manually filled in this data for the non-signatory part of our 
sample, using publicly available sources such as annual disclosure and fund websites where the fund ownership required confirmation. In cases where we were not able to establish the ownership of the fund, we dropped the fund from our sample.

\section{Cultural-Cognitive Pillar Proxy and Data}

The cultural-cognitive pillar calls for a proxy that is an expression of widely held belief systems, and we choose to employ the Global Leadership and Organizational Behavior Effectiveness (GLOBE) study as the most comprehensive dataset known to the authors that can approximate the cultural-cognitive pillar through quantifying common beliefs and shared logics at country level. The GLOBE study is a publicly accessible dataset on cultural attitudes across 62 countries gathered through qualitative surveys in a crossinstitutional research effort. Published in 2004, it empirically establishes nine cultural dimensions that help differentiate between norms, values, and beliefs in different societies. The framework builds on previous literature in the fields of organizational and leadership studies (Hofstede 1980; Inglehart 1997; Schwartz 1994), and has been widely adopted in management literature studying cultural factors (Anderson 2006; Resick et al. 2006).

We focus on three of the nine GLOBE dimensions which are particularly reflective of the values to which responsible investment is most closely aligned with. The first, humane orientation, is defined as the degree to which a collective encourages and rewards fairness, altruism, generosity, caring, and kindness to others. Responsible investment shares these values as evidenced by its advocacy of social issues like labor standards or gender equality, as well as not profiting from social and environmental externalities. In fact, one could argue that the six principles of the PRI themselves aim to embody these values in the context of a fiduciary duty preamble. The second, institutional collectivism is defined as encouraging and rewarding collective distribution of resources and collective action. It is aligned with the collectivistic nature of both the PRI itself where resources are pooled in the form of expertise and effort through working groups and collective corporate engagement initiatives (Dimson et al. 2018), and the RI movement as a way of collectively addressing the global challenge of sustainable development (Aguilera et al. 2007; Brickson 2007). The third dimension is future orientation, defined as engaging in future-oriented behaviors such as delaying gratification, planning, and investing in the future. This dimension corresponds closely to one of the fundamental concepts of RI that short-term profits from environmental and social externalities are best given up in favor of long-term sustainable growth of the global economy.

\section{Control Variables}

To improve the robustness of our analysis, we control for a selection of internal and external factors which are otherwise unaccounted for in Scott's framework.

As we argue that RI adoption requires resources from institutional investors due to its low standardization and learning curve, we control for pension plan size, whereby larger asset owners have less resource limitations. Following existing studies linking management values and board diversity to CSR adoption (Bear et al. 2010; Boulouta 2013; Hafsi and Turgut 2013; Scholtens and Sievänen 2013; Waldman and Siegel 2008), we control for female representation on trustee boards in our sample. We also include holdings turnover to control for an organization's focus on the longterm which signals a pre-existing practical alignment with a well-established responsible investing principle that is longterm ownership (Clark and Hebb 2004; Hebb 2006; Kiernan 2007; Sethi 2005; Thamotheram and Wildsmith 2007). Furthermore, we control for previous involvement of the asset owner in RI using data from 2002, several years prior to the PRI's founding (Sparkes 2002).

We also control for some external factors such as exposure to media coverage of the PRI in the asset owner's domicile country, for the size of the pension market in parallel to the internal factor of AUM size, as well as the overall standard of corporate social responsibility in the country of domicile. To account for the direct effect of peer pressure with regard to signing the PRI, we also include a variable of the number of asset owners already signed up to the initiative, a control linked to DiMaggio and Powell's institutional isomorphism (1983) and mimetic pressures (Dumas and Louche 2011).

\section{Summary Statistics}

Table 1 illustrates the summary of proxy variables to capture the regulative, normative, and cultural-cognitive characteristics of the institutional setting of asset owners in our sample. It also displays the data sources and reasoning underlying our control variables: size, holdings turnover, and gender diversity. Column (1) shows the variable's name, column (2) gives their definition, and column (3) reports the rationale and source of the data used.

Table 2 presents the basic summary statistics of those proxies. Because of the nature of survival data asset owners (observations) drop out from the sample in year $t$ after they joined the PRI in year $t-1$, meaning our panel data is unbalanced by year. Therefore, we present two sets of summary statistics: (1) summary statistics of all variables for the whole sample period 2007-2011 in Panel A; and (2) mean and standard deviation of all variables each year from 2007 to 2010 in Panel B. Panel A columns 1 to 5 report the total 


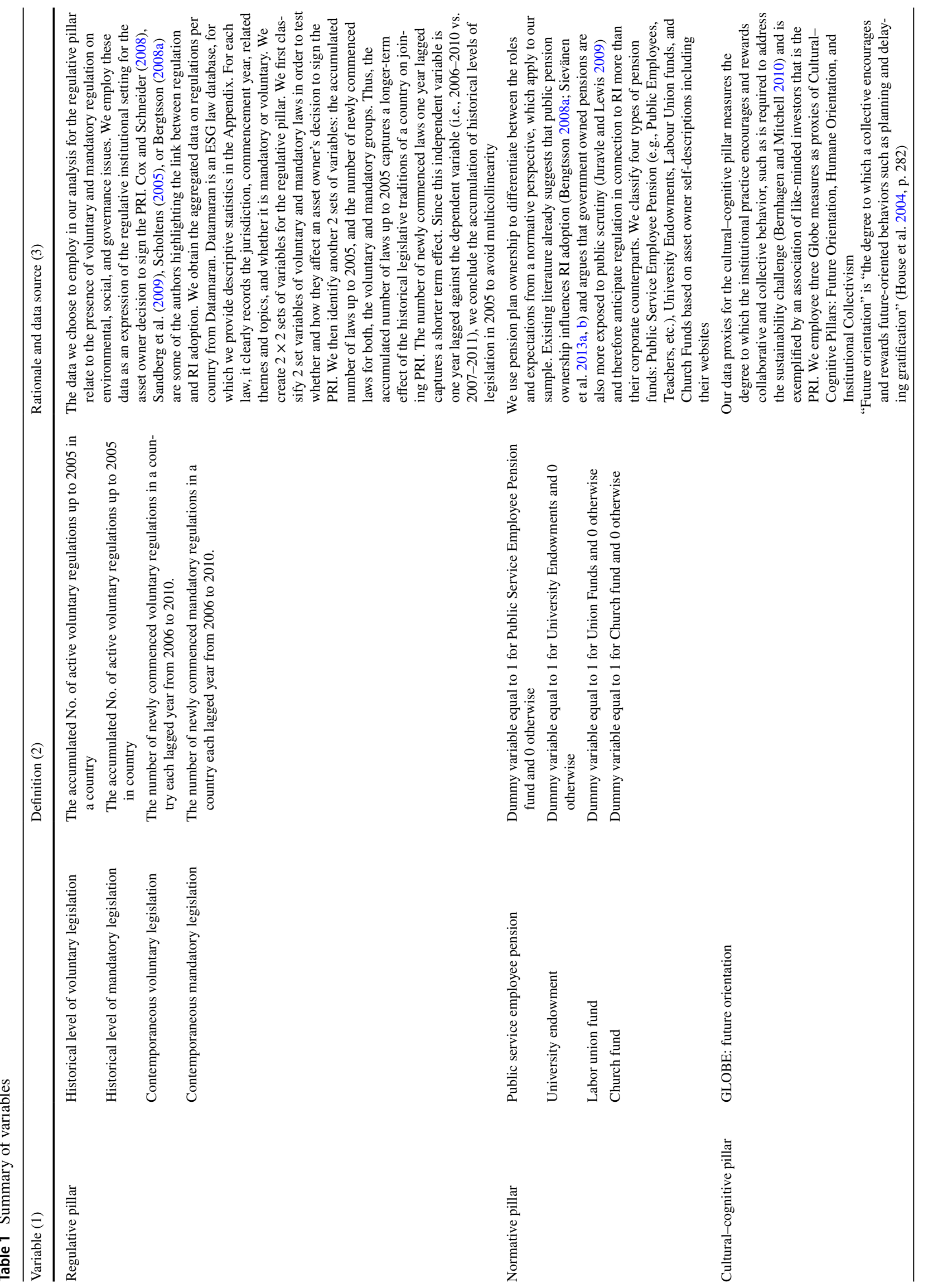




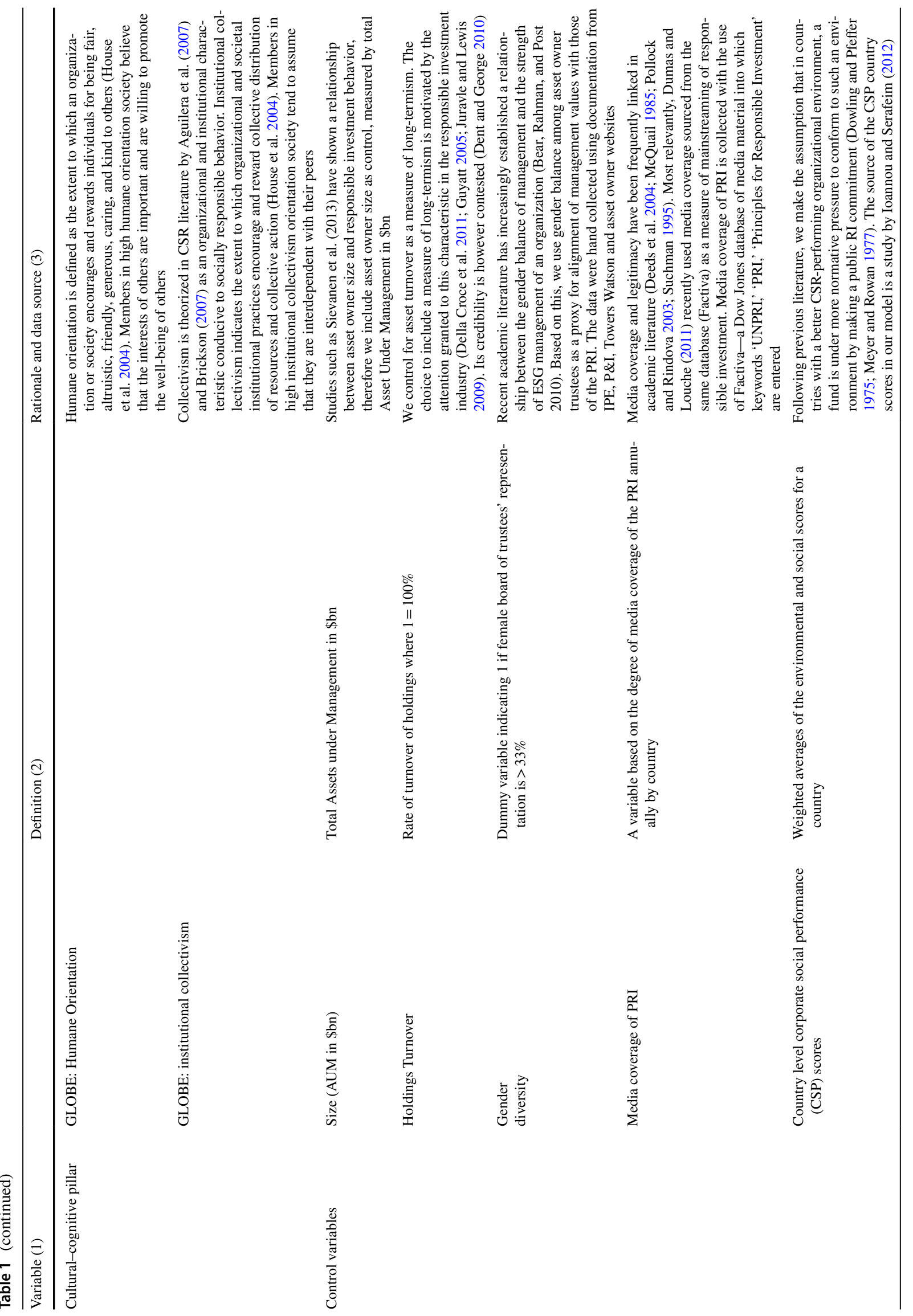




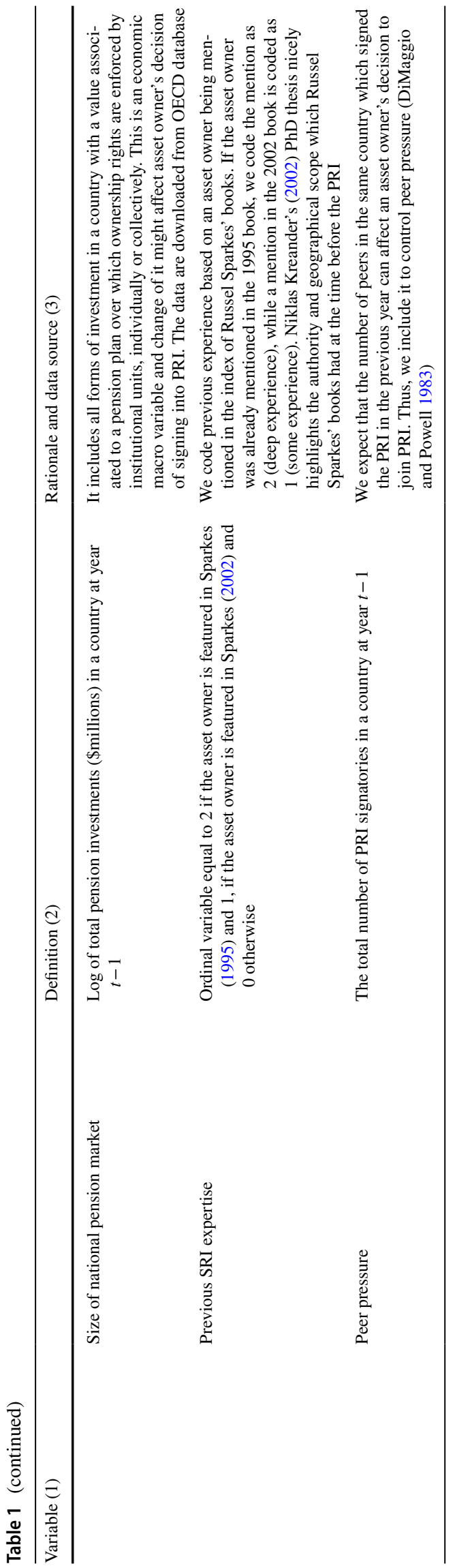

observations, mean, standard deviation, and minimum and maximum values, respectively.

The regulative pillar variables suggest that, on average, the total number of mandatory regulations before 2006 is much higher than that of the voluntary ones, and the former is much more volatile than the latter. This pattern also applies to the newly introduced regulations between 2006 and 2010. Looking at the normative pillar variables, we observe that public employee pension funds account for $35 \%$ of our total sample asset owners for the whole sample period, whereas labor union funds represent $6 \%$, with university endowments and church funds being just fractions of our sample.

While we do not observe particularly noteworthy patterns for the cultural-cognitive variables or the control characteristics, the development of two variables over time is intriguing. First, while the mean and standard deviation of historical voluntary regulation remain relatively stable, the mean of historical mandatory regulation has increased from 28.68 in 2007 to 32.45 in 2011 . This implies that those asset owners who signed the PRI in the early years and therefore dropped out from the sample originated from countries with low historical levels of mandatory legislation, which then in turn increased the mean of the remaining sample in the following year. Secondly, the mean of public service employee pensions decreased from $40 \%$ in 2007 to $33 \%$ in 2011, which indicates the opposite effect of many public service employee pensions signing in the early years of PRI, thereby dropping out of the sample and decreasing the mean of the respective dummy variable.

\section{Survival Analysis}

The purpose of this study is to investigate the influence of institutional aspects on asset owners' decision whether to join the PRI during the period of 2007-2011. ${ }^{6}$ As the PRI signatory data involve right-censoring which occurs when the event of interest (signing the PRI) is not experienced before, or by the last observation, we use survival analysis for censored data as our research method (Cleves et al. 2010; Melnyk et al. 1995). Compared to for instance logit regression, survival analysis (i) does not only consider the information on whether an event occurred (ii) but also the length of time it took for the event to occur. The term survival analysis originates from medical research which studies the literal survival of patients in relation to the event occurrence (i.e., death), whereby avoidance of death for the longest possible time is usually the positive attribute. That said, the statistical technique of survival analysis can equivalently be

\footnotetext{
${ }^{6}$ We are very grateful to an anonymous reviewer for suggesting survival analysis.
} 
applied to a context in which the occurring event itself is the positive attribute (Hosmer and Lemeshow 2008; George et al. 2014).

While survival analysis has not yet been employed in the business ethics literature in particular, it has been used in several contexts in the wider business literature such as IPO survival or the survival of religiously motivated versus conventional financial institutions (Espenlaub et al. 2012; Pappas et al. 2017; Espenlaub et al. 2016a, b; Alandejani et al. 2017).

In our study, the event of interest represents an asset owner signing the PRI. In survival analysis, the dependent variable is the hazard rate which is the conditional probability that an event occurs at a particular time interval (Hosmer and Lemeshow 2008). It is an unobservable variable and controls both the event occurrence and the timing of the event. We first use a parametric Weibull model to address our research question. In general, we specify the parametric hazard function as a function of time and covariates as follows:

$h(t \mid x)=h_{0}(t) r(x, \beta)$

The hazard function, $h(t \mid x)$, as expressed in (1) is a product of two functions. The function, $h_{0}(t)$, is often referred as baseline hazard function which characterizes how the hazard function changes as a function of survival time. It can be casually described as the 'time function.' The other function, $r(x, \beta)$, describes how the hazard function changes as a function of our subject covariates. It can be casually described as the 'characteristics function.' The Weibull parametric model assumes the baseline time function follows Weibull distribution, which is specified as in Eq. (2)

$h_{0}(t)=p t^{p-1}$,

where $p$ is the shape parameter to be estimated. In case $p=1$, the entire time function collapses to 1 and the overall hazard function turns into an exponential regression which is suitable for modelling data where the hazard (i.e., risk) is constant over time.

Following Cox (1972), we define the second characteristics function as

$$
\begin{aligned}
& r(x, \beta)=\exp \left(\beta_{1} x_{1}+\cdots+\beta_{p} x_{p}\right) \\
& =\exp \left(\beta_{1} \text { Regulative Variables }_{i}+\beta_{2} \text { Normative Variables }_{i}\right. \\
& \left.\quad+\beta_{3} \text { Cultural Variables }_{i}+\beta_{4} \text { Controls }_{i}\right),
\end{aligned}
$$

where the covariates, $x_{1}+\cdots+x_{p}$, include regulative, normative, and culture-cognitive institutional variables and control variables, and $\beta_{1}+\cdots+\beta_{p}$ are the model parameters describing the effect of the covariates.

Integrating Eqs. (2) and (3) into Eq. (1), the Weibull parametric regression model is specified as

$$
\begin{aligned}
h(t \mid x)= & p t^{p-1} \exp \left(\beta_{1} \text { Regulative Variables }_{i}\right. \\
& +\beta_{2} \text { Normative Variables }_{i} \\
& \left.+\beta_{3} \text { Cultural Variables }_{i}+\beta_{4} \text { Controls }_{i}\right)
\end{aligned}
$$

where $h(t \mid x)$ is the hazard at time (t) for a given set of covariates $x_{1}+\cdots+x_{p}$. While in a classic survival analysis, a hazard ratio (HR) greater than one indicates that the asset owner is more likely to join the PRI, and a ratio less than one means it is less likely to join the PRI, we use $\beta=\ln (\widehat{H R})$ to transform the hazard ratio into coefficient estimates with a default value of zero, where positive and negative values indicate an over-proportional and under-proportional probability of signing the PRI, respectively.

The Weibull parametric model takes the form of the Cox hazards model but assumes a parametric form on the baseline hazard $\left(h_{0}(t)\right)$ (Clark et al. 2007). It is suitable for modelling data with changing hazard rates that either increases or decreases exponentially overtime. In contrast, the Cox model does not specify the baseline hazard function (Hosmer and Lemeshow 2008). It uses a non-parametric Aalen-Breslow estimator to estimate the hazard function. While the PRI experienced rather exponential growth in signatories during its first 5 years, we use a semi-parametric Cox hazards model as robustness test.

\section{Discussion of Results}

\section{Summary of Survival Data}

We conduct some univariate analysis before proceeding to more complicated models. We first present summary statistics of our survival data in Table 3. Column (1) reports the total number of asset owners and observations. Columns (2) to (5) show the mean, minimum, median, and maximum per asset owner, respectively. We document 667 asset owners in total. 163 of these asset owners, roughly $24 \%$ of sample size, signed into the PRI during the formative first 5 years of its existence. While the first batch of asset owners signed PRI in 2007 and the last batch in 2011, the fact that the mean asset owner signed in 2010 and the median asset owner signed in 2011 underline the exponential growth which the PRI experienced during these first 5 years.

\section{Results of Survival Analysis}

Our results provide evidence of the influence of all three institutional pillars on asset owner likelihood of signing the PRI, however, to varying degrees. The normative aspect from an institutional perspective and the cognitive-cultural aspect have the strongest relationships with asset owner PRI adoption, followed by to a lesser extend the regulative 
pillar. We report our main results of the Weibull parametric proportional hazards model in Table $4 .{ }^{7}$ Columns (1) to (3) illustrate univariate analysis results and columns (4) to (7) show variamultivariate analysis results. As explained, we report coefficient estimates instead of hazard ratios in a manner consistent with traditional regression reporting format.

\section{Regulative Pillar}

Regarding the effect of ESG regulation on the decision of asset owners to join the PRI, we look at the results from fixed long-term and varying short-term regulatory perspectives. First, while the long-term accumulated number of additional voluntary regulations has a statistically positive effect on the decision to join the PRI, long-term mandatory regulation appears to discourage adoption of the PRI. Secondly, we find that contemporary voluntary and mandatory regulations have no effect on joining the PRI, after controlling for all related variables. These results indicate that asset owners from countries with a traditionally (up to 2005) more mandatory ESG regulative environment are somewhat reluctant to become members of PRI, however, asset owners from a country with historically more voluntary ESG regulations tend to be more inclined to join the PRI. The relationship holds for newly introduced voluntary regulation during our sample years, but changes for mandatory regulation, whereas the introduction of new binding regulation in the years (2006-2010) has a positive, although not statistically significant, effect on asset owners signing the PRI.

In interpreting these results from a conceptual perspective, we follow Scott's (1995) view of regulative systems as a spectrum from the diffuse and informal (closer and complimentary to the normative and cultural mechanisms) to the highly formalized and coercive in distinguishing between voluntary and mandatory ESG regulation. The findings for the regulative pillar are surprising, suggesting that an institutional setting characterized by voluntary ESG regulation (informal) is overall more strongly associated with a higher likelihood of asset owners joining the PRI than mandatory regulation (formal). ${ }^{8}$

\footnotetext{
${ }^{7}$ We assess the goodness of fit of the model by visually inspecting the Cox-Snell residuals. The graph indicates that the hazard function broadly follows the 45-degree line with hazard rate being around the expected value of one. The graph is available upon request.

${ }^{8}$ To avoid that our results are affected by multicollinearity between mandatory and voluntary legislation, we have repeated all analysis displayed in Table 4 with marginal voluntary regulation instead of voluntary regulation. The statistical significance of the regulation coefficients stays identical. Marginal voluntary regulation correlates zero with mandatory legislation, as it is the sum of the intercept and residual from an orthogonalization regression of voluntary legislation on mandatory legislation.
}

This is a counterintuitive result considering the potential lowering of barrier to entry to adhering to voluntary standards where compliance with mandatory ones is already achieved. In the context of responsible investment, however, there are two specific factors to take into account. First, that ESG is a field with very low standardization, meaning that complying with one standard may not necessarily work towards removing the barrier to entry to complying with another. Much ESG regulation is focused on reporting, which is very heterogenous and tends to be resource intensive with poorly understood and defined metrics needing to be gathered across complex investment organizations. As a result, asset owners based in jurisdictions with more compulsory ESG regulations may have less resources (time, human, and financial) left available to dedicate to voluntary initiatives such as the PRI after already spending them on complying with binding regulation they are subject to. The second factor would be that in the general context of ESG, compliance with voluntary regulation has reputational and socially legitimizing benefits. However, in an institutional setting that introduces mandatory regulation these benefits are diminished, since what is a minimum legal requirement can no longer act as a positive distinguishing factor.

Multiple studies have argued that regulation is a crucial pillar of RI adoption (Bengtsson 2008a; Gond et al. 2011; Juravle and Lewis 2009; Sandberg et al. 2009). We contribute to this literature with our findings, suggesting that while $\mathrm{RI}$ is in the growth stage, still moving towards standardization and institutionalization (Arjaliès 2010; Louche 2004; Sandberg et al. 2009; Sparkes and Cowton 2004), mandatory regulation may remain narrow in scope and predominantly disclosure-focused, whereas it is the voluntary codes and guidelines that foster and remove the barriers to RI adoption by explaining and suggesting best practice (Jemel-Fornetty et al. 2011). This argument is in line with Sievänen's paper on impediments to asset owner RI adoption (2014), and other literature citing asset owners' struggle with the practical implementation of RI (Majoch et al. 2016; Sievänen et al. 2013b).

A further explanation for the positive effect of voluntary regulation is that it acts as a replacement for mandated law, and as a welcome way for industries to avoid being externally regulated (Campbell 2006; Haigh and Hazelton 2004; Hart 2010; Vogel 2010). In the case of asset owner responsible investment, signing an industry-driven set of principles such as the PRI would send the message that the investment industry needs no binding laws on sustainability as it is already regulating itself with voluntary initiatives. In institutional settings where the emphasis falls on mandatory regulation, voluntary initiatives are not necessarily useful in the same way. The finding makes an interesting contribution to the ongoing academic debate surrounding the adequacy of voluntary codes such as the PRI in the last 15 years as an 
Table 2 Summary statistics of survival analysis sample

\begin{tabular}{|c|c|c|c|c|c|c|c|c|c|c|}
\hline Variables & & $\begin{array}{l}\text { Obs } \\
(1)\end{array}$ & & $\begin{array}{l}\text { Mean } \\
\text { (2) }\end{array}$ & & $\begin{array}{l}\text { SD } \\
(3)\end{array}$ & & $\begin{array}{l}\text { Min } \\
\text { (4) }\end{array}$ & & $\begin{array}{l}\text { Max } \\
(5)\end{array}$ \\
\hline \multicolumn{11}{|l|}{ Panel A: overall summary statistics for 2007-2011 } \\
\hline \multicolumn{11}{|l|}{ Regulative pillar } \\
\hline Historical level of voluntary legislation & & 2881 & & 1.23 & & 0.72 & & 0 & & 2 \\
\hline Historical level of mandatory legislation & & 2881 & & 30.62 & & 33.26 & & 0 & & 78 \\
\hline Contemporaneous voluntary legislation & & 2881 & & 0.40 & & 0.70 & & 0 & & 2 \\
\hline Contemporaneous mandatory legislation & & 2881 & & 1.35 & & 1.82 & & 0 & & 6 \\
\hline \multicolumn{11}{|l|}{ Normative pillar } \\
\hline Public service employee pension & & 2881 & & 0.35 & & 0.48 & & 0 & & 1 \\
\hline University endowment & & 2881 & & 0.01 & & 0.10 & & 0 & & 1 \\
\hline Labor union fund & & 2881 & & 0.06 & & 0.24 & & 0 & & 1 \\
\hline Church fund & & 2881 & & 0.01 & & 0.09 & & 0 & & 1 \\
\hline \multicolumn{11}{|l|}{ Cultural-cognitive pillar } \\
\hline GLOBE: future orientation & & 2881 & & 5.26 & & 0.24 & & 4.49 & & 6.26 \\
\hline GLOBE: humane orientation & & 2881 & & 5.50 & & 0.23 & & 3.6 & & 5.91 \\
\hline GLOBE: institutional collectivism & & 2881 & & 4.39 & & 0.34 & & 3.84 & & 5.60 \\
\hline \multicolumn{11}{|l|}{ Control variables } \\
\hline Size (AUM in \$bn) & & 2881 & & 34.88 & & 65.78 & & 0.01 & & 1072.4 \\
\hline Holdings turnover & & 2881 & & 0.26 & & 0.17 & & 0 & & 1.44 \\
\hline Gender diversity & & 2881 & & 0.22 & & 0.41 & & 0 & & 1 \\
\hline Media coverage of PRI & & 2881 & & 29.14 & & 9.71 & & 0 & & 48.55 \\
\hline $\begin{array}{l}\text { Country level corporate social performance } \\
\text { scores }\end{array}$ & $(\mathrm{CSP})$ & 2881 & & 0.50 & & 0.11 & & 0.19 & & 0.73 \\
\hline Size of national pension market & & 2761 & & 13.90 & & 2.19 & & 1.74 & & 16.23 \\
\hline Previous SRI expertise & & 2881 & & 0.02 & & 0.16 & & 0 & & 2 \\
\hline Peer pressure & & 2881 & & 21.51 & & 17.63 & & 0 & & 68 \\
\hline \multirow[t]{3}{*}{ Variables } & 2007 & & 2008 & & 2009 & & 2010 & & 2011 & \\
\hline & $N=667$ & & $N=587$ & & $N=562$ & & $N=543$ & & $N=522$ & \\
\hline & Mean & SD & Mean & SD & Mean & SD & Mean & SD & Mean & SD \\
\hline
\end{tabular}

Panel B: mean and standard deviation by year 2007-2010

Regulative pillar

\begin{tabular}{lrrrrrrrrrr} 
Historical level of voluntary legislation & 1.22 & 0.71 & 1.23 & 0.72 & 1.24 & 0.72 & 1.24 & 0.72 & 1.25 & 0.73 \\
Historical level of mandatory legislation & 28.68 & 32.65 & 30.22 & 33.16 & 30.81 & 33.29 & 31.45 & 33.53 & 32.45 & 33.81 \\
Contemporaneous voluntary legislation & 0.23 & 0.42 & 0.70 & 0.92 & 0.16 & 0.36 & 0.14 & 0.35 & 0.83 & 0.91 \\
Contemporaneous mandatory legislation & 2.10 & 2.58 & 0.35 & 0.63 & 1.07 & 0.94 & 1.02 & 1.01 & 2.15 & 2.17 \\
Normative pillar & & & & & & & & & \\
Public service employee pension & 0.40 & 0.49 & 0.36 & 0.48 & 0.34 & 0.48 & 0.33 & 0.47 & 0.33 & 0.47 \\
University endowment & 0.01 & 0.10 & 0.01 & 0.10 & 0.01 & 0.10 & 0.01 & 0.10 & 0.01 & 0.11 \\
Labor union fund & 0.08 & 0.27 & 0.06 & 0.24 & 0.06 & 0.24 & 0.06 & 0.24 & 0.06 & 0.23 \\
Church fund & 0.01 & 0.09 & 0.01 & 0.09 & 0.01 & 0.08 & 0.01 & 0.09 & 0.01 & 0.08 \\
Cultural-cognitive pillar & & & & & & & & & \\
GLOBE: future orientation & 5.26 & 0.25 & 5.26 & 0.24 & 5.26 & 0.24 & 5.26 & 0.23 & 5.27 & 0.22 \\
GLOBE: humane orientation & 5.51 & 0.22 & 5.50 & 0.23 & 5.50 & 0.23 & 5.50 & 0.23 & 5.50 & 0.23 \\
GLOBE: institutional collectivism & 4.41 & 0.36 & 4.39 & 0.33 & 4.38 & 0.33 & 4.38 & 0.33 & 4.38 & 0.33 \\
Size (AUM in \$bn) & & & & & & & & & \\
Holdings turnover & 35.40 & 66.86 & 34.28 & 65.11 & 34.98 & 66.17 & 34.40 & 64.89 & 35.26 & 65.90 \\
Gender diversity & 0.27 & 0.17 & 0.26 & 0.17 & 0.26 & 0.17 & 0.26 & 0.17 & 0.26 & 0.16 \\
Media coverage of PRI & 0.23 & 0.42 & 0.21 & 0.41 & 0.21 & 0.41 & 0.21 & 0.41 & 0.21 & 0.41 \\
& 29.02 & 9.72 & 29.10 & 9.55 & 29.12 & 9.72 & 29.28 & 9.86 & 29.25 & 9.74 \\
\hline
\end{tabular}


Table 2 (continued)

\begin{tabular}{|c|c|c|c|c|c|c|c|c|c|c|}
\hline \multirow[t]{3}{*}{ Variables } & \multirow{2}{*}{\multicolumn{2}{|c|}{$\frac{2007}{N=667}$}} & \multirow{2}{*}{\multicolumn{2}{|c|}{$\begin{array}{l}2008 \\
N=587\end{array}$}} & \multirow{2}{*}{\multicolumn{2}{|c|}{$\begin{array}{l}2009 \\
N=562\end{array}$}} & \multirow{2}{*}{\multicolumn{2}{|c|}{$\begin{array}{l}2010 \\
N=543\end{array}$}} & \multirow{2}{*}{\multicolumn{2}{|c|}{$\begin{array}{l}2011 \\
N=522\end{array}$}} \\
\hline & & & & & & & & & & \\
\hline & Mean & SD & Mean & SD & Mean & SD & Mean & SD & Mean & SD \\
\hline $\begin{array}{l}\text { Country level corporate social perfor- } \\
\text { mance (CSP) scores }\end{array}$ & 0.50 & 0.11 & 0.50 & 0.11 & 0.49 & 0.11 & 0.49 & 0.11 & 0.49 & 0.11 \\
\hline Size of national pension market & 13.83 & 2.27 & 13.71 & 2.16 & 13.88 & 2.15 & 14.03 & 2.16 & 14.08 & 2.18 \\
\hline Previous SRI expertise & 0.04 & 0.22 & 0.02 & 0.14 & 0.02 & 0.13 & 0.02 & 0.13 & 0.02 & 0.14 \\
\hline Peer pressure & 14.51 & 11.26 & 14.23 & 11.26 & 21.27 & 15.41 & 27.03 & 18.35 & 33.14 & 22.75 \\
\hline
\end{tabular}

Panel A presents the basic summary statistics of our interest proxies for the whole sample period from 2007 to 2011 . Column 1 to Column 5 report the total observation, mean, standard deviation, minimum, and maximum value, respectively

Panel B reports the changes of mean and standard deviation of all variables for the individual years of 2007 to 2011 . Since the sample size in our survival analysis naturally shrinks by asset owners signing up to the PRI, we believe it is interesting to inspect the distributional means and standard deviations of the explanatory variables by the year. There are two noteworthy observations in this panel. First, while the mean and standard deviation of historical voluntary regulation remain relatively stable, the mean of historical mandatory regulation has increased from 28.68 in 2007 to 32.45 in 2011. This implies that those asset owners who signed PRI in the early years and therefore dropped out from the sample originated from countries with low historical levels of mandatory legislation, which then in turn increased the mean of the remaining sample in the following year. Secondly, the mean of public service employee pensions decreased from $40 \%$ in 2007 to $33 \%$ in 2011 , which indicates the opposite effect of many public services employee pensions signing in the early years of PRI, thereby dropping out of the sample and decreasing the mean of the respective dummy variable

alternative to regulation (Perez-Batres et al. 2012; Sethi and Schepers 2013, 2014).

As documented by the PRI's own Global Guide to Responsible Investment Regulation (PRI 2016b), there is a very clear and aggressive upward trend in the proliferation of responsible investment policies, which have been on a steep incline consistently since 2007. It is important to note that although the PRI takes policy engagement as one of its goals and supports the development of guidelines and regulations fostering growth of sustainable finance, in the very first 5 years of the PRI's existence, which are our sample period, any increase in regulation is very unlikely to have taken place as a result of the PRI's own activity due to the timeframe of policy engagement and the PRI signatories' own history of activity around it. According to the PRI's 2014 report on policy engagement, only about onethird of all signatories reported any involvement in policy engagement. The same report draws attention to the time it takes for policy engagement to bear fruit, citing a series of case studies with 3 to 7 year timelines (PRI 2014). We test this statistically by regressing legislation from the period 2008-2012 on PRI signing in the 2007-2011 with statistically insignificant results, although we do recognize that in years following our sample period it is possible that that effect would be more likely to occur.

\section{Normative Pillar}

The normative pillar, showing strong associations with PRI adoption by asset owners, relates to the influence of institutional settings on organizational behavior via an understanding of obligations, rights, and expected and appropriate behavior (Scott 1995). In examining the conditions of asset owner adoption of an RI initiative like the PRI, we take into account the biggest differentiator between these normative aspects to asset owners, that is plan ownership.

Indeed, we find that a public service employee pension fund is about 1.01 times more likely than a corporate pension fund to adopt the PRI, and this result is statistically significant at $1 \%$ even after controlling for other relevant factors. Similarly, the coefficient of labor unions is positive and statistically significant in both univariate and multivariate analysis. However, it seems that university endowments and church funds perform indifferently compared to other types of pensions in their adoption of the PRI. These results clearly support our hypothesis that the normative aspect of the institutional setting explains asset owner adoption of the PRI, whereby public service employee pension funds and labor unions are more likely to sign. The strong association between PRI adoption and public ownership can be attributed to public pensions' expected role, and the boundaries of what is acceptable for them to do that differentiate them from corporate plans. Flagship examples of the application of such normative systems are the Norwegian Environmental Fund which was from its inception mandated to carry out environmentally based screening on its investments to align with the interests of future generations beyond shorter term financial performance objectives, as well as the ethical guidelines for the Norwegian Government Pension Fund established in 2004 (Bengtsson 2008a). 
Table 3 Summary of survival data

\begin{tabular}{|c|c|c|c|c|c|}
\hline \multirow[t]{2}{*}{ Category } & \multirow[t]{2}{*}{ Total (1) } & \multicolumn{4}{|c|}{ Per asset owner } \\
\hline & & Mean (2) & $\operatorname{Min}(3)$ & Median (4) & $\operatorname{Max}(5)$ \\
\hline $\begin{array}{l}\text { No. of asset } \\
\text { owners }\end{array}$ & 667 & & & & \\
\hline No. of records & 2881 & 4 & 1 & 5 & 5 \\
\hline $\begin{array}{l}\text { Time to sign } \\
\text { PRI }\end{array}$ & & 2010 & 2007 & 2011 & 2011 \\
\hline PRI signatories & 163 & $24 \%$ & 0 & 0 & 1 \\
\hline $\begin{array}{l}\text { Non-PRI } \\
\text { signatories }\end{array}$ & 504 & $76 \%$ & 0 & 0 & 1 \\
\hline
\end{tabular}

This table presents summary statistics of our survival data 20072011. Column (1) report the total number. Columns (2) to (5) show the mean, minimum, median, and maximum, respectively

Our results are in line with Juravle and Lewis (2009) who confirm in their interview-based study that public pension funds have been the pioneers of responsible investment because they are more scrutinized by the public in terms of their investments' alignment with societal norms (i.e., their expected role) and not affected by conflicts of interest arising from being funded by a corporate sponsor (i.e., boundaries of what is acceptable). Their findings put into qualitative context the data-driven results showing a similar relationship both in the present study and in the previously mentioned Sievänen et al. (2013a, b) survey paper on the drivers of asset owner RI adoption, and firmly link them to our theoretical understanding of the role of normative institutional systems in determining organizational behavior (Scott 1995).

\section{Cognitive-Cultural Pillar}

The cognitive-cultural aspect of the institutional setting is also associated with a higher likelihood of PRI adoption by asset owners. In our analysis, this is manifested by asset owners from institutional backgrounds already largely aligned with some of the values underpinning the RI movement being more likely to sign the PRI during the sample years 2007-2011. Specifically, a one unit increase in our GLOBE humane orientation and GLOBE institutional collectivism variables leads to 1.627 and 1.233 times higher practice of joining the PRI respectively in the model with all controls. GLOBE future orientation is the one of the three tested proxies for the cultural-cognitive pillar that seems to have little impact on joining PRI. The relationship changes from slightly negative run only with the other cultural proxies or control variables, to positive but insignificant in the full model. While surprising, this may be explained to a degree by future orientation's negative correlation with the other two GLOBE variables we include in our model. Although one of the variables used does not show a clear relationship with signing the PRI, based on the overall results for this pillar we are inclined to conclude that the cognitive-cultural aspect of the asset owner's institutional setting has an influence on its participation in an initiative like the PRI.

The previously brought up example of Nordic asset owners serves as an illustration of this effect. By contrast, the US-scoring lower on collectivism than countries grouped in the Nordic cluster in the GLOBE study as well as in other country level datasets focusing specifically on individualism versus collectivism (Allik and Realo 2004) - is consistently shown to lag behind Europe in terms of attitudes towards responsible investing (Royal Bank of Canada 2018) and the proportion of total assets under management invested in SRI strategies: $53 \%$ in Europe versus 22\% in the US according to the Global Sustainable Investment Alliance (GSIA 2016). When thinking of the Nordics versus the US, humane orientation and collectivism are indeed reflected more in the general institutional settings of Nordic countries than the US, whereby a higher level of income taxes in the Nordics are redistributed through Nordic model welfare policies, for example, universal healthcare that the US lacks. The concept of giving up a higher proportion of your personal wealth for the benefit of society at large is in parallel with the concept of universal ownership and responsible investing whereby individual institutional investors prioritize a sustainable economy respectful of limits on natural resources and society over financial profits reaped at the cost of environmental and social externalities. ${ }^{9}$

For asset owners in particular, the question of the cognitive-cultural characteristics of their institutional setting coming into play in their decision making can be explained by them having to represent a widely dispersed group of key stakeholders. For drafting signatories of the PRI such as the Norwegian Government Pension Fund, Canadian Pension Plan Investment Board, or the French Caisse des Dépôts et Consignations and Pensions Reserve Fund it essentially equates to the general public in their respective countries. For others that are not state asset owners, like the Dutch PGGM for example, also a drafting signatory to the PRI, the number of beneficiaries still accounts for $15 \%$ of the Dutch population. A beneficiary base dispersed enough to be representative of society at large would suggest that the asset owner's actions are likely to align with the wider

\footnotetext{
9 To further investigate a potential 'Nordic effect,' we add a dummy for asset owners from the Denmark, Finland, Norway, and Sweden to our model and actually find this to be a significantly positive determinant of the decision to sign the PRI. This evidence is consistent with a unique role of the Nordics in supporting Sustainable Finance that has also been studied, for instance, by Hoepner and Schopohl (2018a) and maybe reinforced by the recent nobel peace prize nomination of Swedish teen climate activist Greta Thunberg.
} 
Table 4 Parametric Weibull model result

\begin{tabular}{|c|c|c|c|c|c|c|c|}
\hline \multirow[t]{2}{*}{ Variables } & \multicolumn{7}{|c|}{ Time to event of signing PRI } \\
\hline & (1) & (2) & (3) & (4) & (5) & (6) & (7) \\
\hline $\begin{array}{c}\text { Historical level } \\
\text { of voluntary } \\
\text { legislation }\end{array}$ & $0.329 * *(2.49)$ & & & $0.275^{*}(1.94)$ & & & $0.394 * * *(2.65)$ \\
\hline $\begin{array}{c}\text { Historical level } \\
\text { of mandatory } \\
\text { legislation }\end{array}$ & $\begin{array}{c}-0.028 * * * \\
(-5.31)\end{array}$ & & & $\begin{array}{c}-0.030 * * * \\
(-4.67)\end{array}$ & & & $\begin{array}{c}-0.033 * * * \\
(-4.75)\end{array}$ \\
\hline $\begin{array}{l}\text { Contemporane- } \\
\text { ous voluntary } \\
\text { legislation }\end{array}$ & $0.297 * *(1.97)$ & & & $0.279 *(1.84)$ & & & $0.200(1.30)$ \\
\hline $\begin{array}{l}\text { Contemporane- } \\
\text { ous mandatory } \\
\text { legislation }\end{array}$ & $0.039(0.50)$ & & & $0.043(0.56)$ & & & $0.020(0.25)$ \\
\hline $\begin{array}{l}\text { Public service } \\
\text { employee pen- } \\
\text { sion }\end{array}$ & & $1.168 * * *(7.10)$ & & & $0.957 * * *(5.57)$ & & $1.010 * * *(5.77)$ \\
\hline $\begin{array}{l}\text { University endow- } \\
\text { ment }\end{array}$ & & $-0.193(-0.19)$ & & & $0.318(0.31)$ & & $0.993(0.96)$ \\
\hline Labor union fund & & $1.003 * * *(4.68)$ & & & $0.986 * * *(4.44)$ & & $0.673 * * *(2.87)$ \\
\hline Church fund & & $1.252 *(1.74)$ & & & $0.993(1.37)$ & & $1.208(1.63)$ \\
\hline $\begin{array}{l}\text { GLOBE: future } \\
\text { orientation }\end{array}$ & & & $\begin{array}{r}-0.729 * * \\
(-2.38)\end{array}$ & & & $-0.654 *(-1.91)$ & $0.262(0.77)$ \\
\hline $\begin{array}{l}\text { GLOBE: humane } \\
\text { orientation }\end{array}$ & & & $2.104 * * *(3.40)$ & & & $1.036 * *(2.23)$ & $1.627 * *(2.52)$ \\
\hline $\begin{array}{l}\text { GLOBE: institu- } \\
\text { tional collectiv- } \\
\text { ism }\end{array}$ & & & $1.339 * * *(6.77)$ & & & $1.168 * * *(4.13)$ & $1.233 * * *(4.29)$ \\
\hline $\begin{array}{l}\text { Size (AUM in } \\
\quad \$ b n)\end{array}$ & & & & $-0.000(-0.32)$ & $-0.001(-0.74)$ & $0.000(0.05)$ & $-0.001(-0.59)$ \\
\hline Holdings turnover & & & & $0.596(1.35)$ & $0.540(1.18)$ & $0.627(1.35)$ & $1.206 * * *(2.66)$ \\
\hline Gender diversity & & & & $0.655^{* * *}(3.70)$ & $0.351 * *(2.00)$ & $0.573 * * *(3.26)$ & $0.646^{* * *}(3.45)$ \\
\hline $\begin{array}{l}\text { Media coverage } \\
\text { of PRI }\end{array}$ & & & & $-0.007(-0.83)$ & $0.001(0.11)$ & $0.000(0.02)$ & $-0.002(-0.26)$ \\
\hline $\begin{array}{l}\text { Country level } \\
\text { corporate social } \\
\text { performance } \\
\text { (CSP) scores }\end{array}$ & & & & $1.632 *(1.91)$ & $3.377 * * *(4.33)$ & $1.507(1.61)$ & $-0.809(-0.80)$ \\
\hline $\begin{array}{l}\text { Size of national } \\
\text { pension market }\end{array}$ & & & & $0.163 * *(2.29)$ & $-0.026(-0.46)$ & $0.014(0.26)$ & $0.161 * *(1.99)$ \\
\hline $\begin{array}{l}\text { Previous SRI } \\
\text { expertise }\end{array}$ & & & & $1.112 * * *(4.16)$ & $0.617 * *(2.27)$ & $1.210 * * *(4.56)$ & $0.852 * * *(3.06)$ \\
\hline Peer pressure & & & & $\begin{array}{c}-0.021 * * * \\
(-3.27)\end{array}$ & $-0.009(-1.36)$ & $-0.008(-1.25)$ & $-0.015 * *(-2.24)$ \\
\hline $\operatorname{ln\_ p}$ & $6.682 * * *(90.83)$ & $6.696 * * *(91.34)$ & $6.693 * * *(90.86)$ & $6.798 * * *(91.41)$ & $6.768 * * *(88.30)$ & $6.757 * * *(88.05)$ & $6.821 * * *(92.27)$ \\
\hline Observations & 2881 & 2881 & 2881 & 2761 & 2761 & 2761 & 2761 \\
\hline
\end{tabular}

We run parametric Weibull model on the three sets of interest variables, namely four regulative, four normative, and three cultural (Cultural alignment) aspects of Scott (1995) institutional theory. The control variables are firm specific (size, holdings turnover, previous SRI expertise and board gender diversity) and country-specific (Media Coverage of PRI, CSP score, Size of National Pension Market, Peer Pressure) characteristics. All variables are defined in Table 1. The dependent variable is time to event of signing PRI. Columns (1) to (3) report the estimated coefficients and (t statistics) for the three sets of interest variables without controlling firm specific characteristics, respectively. Columns (4) to (6) report the estimated coefficients and (t statistics) for our three sets of interest variables by controlling for the firm and country-specific characteristics, respectively. Column (7) presents the estimated coefficients and (t statistics) for the Weibull model including all covariates. We also report ln_p, the shape parameter of the baseline function

$*, * *, * * *$ Denote statistical significant at the 10,5 , and $1 \%$ levels, respectively

national attitudes as reflective of their stakeholder base, in the absence of more direct and explicit direction such as is received e.g., by asset managers from the asset owner when an investment mandate is assigned. In the particular case of responsible investment, this would mean that if its principal values were not supported by the general population in the 
asset owner's country, the asset owner would be less likely to commit to practicing responsible investment by signing the PRI. Our results confirm this.

Evidence that the PRI resonates more with asset owners from cognitive-cultural institutional backgrounds that are better aligned with it points to the crucial importance of shared conceptions and values at societal level in the adoption of emerging logics such as RI, a concept already widely discussed in literature on the growth of responsible investment (Arjaliès 2010, Bengtsson 2008a; Sandberg et al. 2009; Scholtens and Sievänen 2013). As Scott (1995) explains, the hyphenated label cultural-cognitive signifies that the evaluation of such an emerging logic (cognitive process) happens within the external cultural framework (cultural categories).

\section{Robustness Tests and Directions for Future Research}

Beyond our test for reverse causality in the regulative pillar, we complement our parametric Weibull model with a semiparametric Cox model to understand the robustness of each coefficient estimate. Table 5 reports the semi-parametric Cox model results. ${ }^{10}$ It shows that the signs and significance levels of our variables of interest remain virtually identical and hence our results enjoy a high degree of robustness. We also find that the coefficient estimates of parametric hazards model are comparable to those produced by the non-parametric Cox model, indicating that our assumption of Weibull distribution of baseline hazards model is reliable.

We also conduct three specific robustness tests of the curious negative effect of historical levels of mandatory legislation on signing the PRI. First, we manually integrate the Datamaran and CandS databases into one joint database, which results in small increase of coverage in the number of mandatory and voluntary legislation by $5.0 \%$ and $12.8 \%$, respectively. Then we re-run our Weibull and our Cox models with the joint database instead of just Datamaran but find historical levels of mandatory legislation to have the same negative effect at the same significance level across any specification. Second, we introduce a dummy for the 22 socalled 'Red List States' which voted persistently Republican in all presidential elections since $2000 .{ }^{11}$ Given the results of Hong and Kostovetsky (2012) and especially Hoepner and Schopohl (2018b), pension funds from red states may have a

\footnotetext{
${ }^{10}$ We conduct a satisfactory Cox Proportional assumption test. The results are available upon request.

11 These '22 Red List' states are Alabama, Alaska, Arkansas, Arizona, Georgia, Idaho, Kansas, Kentucky, Louisiana, Mississippi, Missouri, Montana, Nebraska, North Dakota, Oklahoma, South Carolina, South Dakota, Tennessee, Texas, Utah, West Virginia, and Wyoming.
}

negative predisposition towards PRI and substantially affect our results. The introduction of this dummy, however, does not affect our results in any meaningful manner.

Third, we re-run our Weibull and our Cox models excluding any US asset owners. When excluding the entire US, the level of historical mandatory legislation remains a significant negative factor impacting the decision to sign PRI, albeit at a lower significance level in the Weibull model. The significance in the Cox model remains the same. Curiously though, the importance of voluntary legislation amplifies somewhat when excluding the entire US. That said, the importance of voluntary legislation decreased in the Cox model when compared with the Weibull model and fell further when replacing Datamaran with the joint database, which implies that the negative effect of historical levels of mandatory legislation is more robust than the positive effect of historical levels of voluntary legislation.

The present study is a first attempt to systematically assess the influence of institutional settings on asset owner adoption of the PRI with the use of public data and as such offers many possible directions for future research in the field. Having conducted a large, global study of asset owners' decision to sign the PRI, we acknowledge we were somewhat limited in our choice of proxies and the level of insight gained when compared with complementary, smaller scale studies such as Scholtens and Sievanen (2013) or studies such as Majoch et al. (2016) which use confidential data reported directly by PRI signatories themselves.

Hence, we consider more granular research needed which investigates the specific nature of regulation and its effectiveness. Moreover, our finding of the positive effect of voluntary regulation would benefit from further conceptual and empirical exploration in the context of institutional investors. The role of corporate self-regulation in sustainability is already being discussed widely in academic literature (Haufler 2013; Moon 2007; Gond et al. 2011), laying the groundwork for similar work on the institutional investment space. Our findings call for further research into the nuances of how policy and regulation continue to play into the development of responsible investment, a topic that will continue to be relevant especially as we dedicate increasing collective resources into the formulation of such policy (see for example the High-Level Expert Group on Sustainable Finance established by the European Commission to provide recommendations on the transition to a more sustainable economy and the Technical Expert Group subsequently appointed to advise on the implementation of these recommendations). Likewise, the cultural-cognitive aspect of the institutional settings has yielded strong results with two of our chosen variables but ambiguous with one of them, opening up a clear direction for additional research into particular cultural and cognitive characteristics that drive asset owners to adopt 
Table 5 Semi-parametric Cox model result

\begin{tabular}{|c|c|c|c|c|c|c|c|}
\hline \multirow[t]{2}{*}{ Variables } & \multicolumn{7}{|c|}{ Time to event of signing PRI } \\
\hline & (1) & (2) & (3) & (4) & (5) & (6) & (7) \\
\hline $\begin{array}{l}\text { Historical level } \\
\text { of voluntary } \\
\text { legislation }\end{array}$ & $0.307 * *(2.27)$ & & & $0.189(1.32)$ & & & $0.267 *(1.80)$ \\
\hline $\begin{array}{l}\text { Historical level } \\
\text { of mandatory } \\
\text { legislation }\end{array}$ & $\begin{array}{c}-0.027 * * * \\
(-5.15)\end{array}$ & & & $\begin{array}{c}-0.022 * * * \\
(-3.68)\end{array}$ & & & $\begin{array}{c}-0.026 * * * \\
(-3.86)\end{array}$ \\
\hline $\begin{array}{l}\text { Contemporane- } \\
\text { ous voluntary } \\
\text { legislation }\end{array}$ & $0.323 * *(2.20)$ & & & $0.285^{*}(1.86)$ & & & $0.234(1.52)$ \\
\hline $\begin{array}{l}\text { Contemporane- } \\
\text { ous mandatory } \\
\text { legislation }\end{array}$ & $0.062(0.82)$ & & & $0.053(0.69)$ & & & $0.080(1.02)$ \\
\hline $\begin{array}{l}\text { Public service } \\
\text { employee pen- } \\
\text { sion }\end{array}$ & & $1.106 * * *(6.72)$ & & & $1.030 * * *(5.95)$ & & $1.061 * * *(6.11)$ \\
\hline $\begin{array}{l}\text { University } \\
\text { endowment }\end{array}$ & & $-0.160(-0.16)$ & & & $0.323(0.32)$ & & $0.699(0.69)$ \\
\hline $\begin{array}{l}\text { Labor union } \\
\text { fund }\end{array}$ & & $0.960 * * *(4.48)$ & & & $0.844 * * *(3.78)$ & & $0.559 * *(2.41)$ \\
\hline Church fund & & $1.175(1.63)$ & & & $1.078(1.49)$ & & $1.225 *(1.67)$ \\
\hline $\begin{array}{l}\text { GLOBE: future } \\
\text { orientation }\end{array}$ & & & $\begin{array}{r}-0.684 * * \\
(-2.25)\end{array}$ & & & $\begin{array}{r}-0.610^{*} \\
(-1.74)\end{array}$ & $0.214(0.62)$ \\
\hline $\begin{array}{l}\text { GLOBE: } \\
\text { humane orien- } \\
\text { tation }\end{array}$ & & & $1.898 * * *(3.14)$ & & & $1.110 * *(2.57)$ & $1.382 * * *(2.67)$ \\
\hline $\begin{array}{l}\text { GLOBE: } \\
\text { institutional } \\
\text { collectivism }\end{array}$ & & & $1.227 * * *(6.22)$ & & & $1.174 * * *(3.97)$ & $1.131 * * *(3.89)$ \\
\hline $\begin{array}{l}\text { Size (AUM in } \\
\text { \$bn) }\end{array}$ & & & & $0.000(0.03)$ & $-0.001(-0.40)$ & $0.000(0.26)$ & $-0.000(-0.03)$ \\
\hline $\begin{array}{l}\text { Holdings turno- } \\
\text { ver }\end{array}$ & & & & $0.409(0.91)$ & $0.449(0.98)$ & $0.579(1.24)$ & $0.974 * *(2.14)$ \\
\hline Gender diversity & & & & $0.625 * * *(3.55)$ & $0.378 * *(2.14)$ & $0.623 * * *(3.53)$ & $0.620 * * *(3.38)$ \\
\hline $\begin{array}{l}\text { Media coverage } \\
\text { of PRI }\end{array}$ & & & & $-0.002(-0.30)$ & $0.003(0.38)$ & $0.004(0.47)$ & $0.001(0.11)$ \\
\hline $\begin{array}{l}\text { Country level } \\
\text { corporate } \\
\text { social perfor- } \\
\text { mance (CSP) } \\
\text { scores }\end{array}$ & & & & $1.568 *(1.82)$ & $2.704 * * *(3.45)$ & $1.019(1.06)$ & $-0.735(-0.71)$ \\
\hline $\begin{array}{l}\text { Size of national } \\
\text { pension } \\
\text { market }\end{array}$ & & & & $-0.008(-0.12)$ & $\begin{array}{c}-0.154 * * * \\
(-3.10)\end{array}$ & $\begin{array}{r}-0.098 * * \\
(-2.05)\end{array}$ & $-0.032(-0.47)$ \\
\hline $\begin{array}{l}\text { Previous SRI } \\
\text { expertise }\end{array}$ & & & & $0.853 * * *(3.35)$ & $0.389(1.50)$ & $0.900 * * *(3.50)$ & $0.625 * *(2.41)$ \\
\hline Peer pressure & & & & $0.005(0.66)$ & $0.021 * * *(3.01)$ & $0.020 * * *(2.99)$ & $0.015 *(1.92)$ \\
\hline Observations & 2881 & 2881 & 2881 & 2761 & 2761 & 2761 & 2761 \\
\hline
\end{tabular}

We run semi-parametric Cox model on the three sets of interest variables, namely four regulative, four normative, and three cultural aspects of Scott (1995) institutional theory. The control variables are four firm-specific and four country-specific characteristics. All variables are defined in Table 1. The dependent variable is time to event of signing PRI. Columns (1) to (3) report the estimated coefficients and ( $t$ statistics) for our three sets of interest variables without controlling firm specific characteristics, respectively. Columns (4) to (6) report the estimated coefficients and $(t$ statistics) for our three sets of interest variables by controlling firm specific characteristics, respectively. Column (7) presents the estimated coefficients and ( $t$ statistics) for the Cox model including all covariates

$*, * *, * * *$ Denote statistical significant at the 10,5 , and $1 \%$ levels, respectively 
responsible investment practices and join self-regulatory initiatives in the space like the UN PRI.

In the context of not only asset owner but also general institutional investor membership, research into the PRI's growth in later periods than the present paper undertakes would be an interesting and useful continuation. Post-2011 the nature of the PRI as a voluntary association changed slightly as it started introducing mandatory enforced requirements of its members in the form of fees and public reporting. This direction of travel continued more recently as the PRI announced it would introduce minimum requirements in terms of progress and level of ESG integration for its members and delist those who do not demonstrate a minimum effort. This marks a departure from the founder James Gifford's initial idea for the PRI as a way to simply attract as many investors as possible to ESG integration, or in his own words 'get people in the tent, for whatever reason' (Majoch et al. 2016). In late 2013, James Gifford resigned from his role as founder CEO at the PRI, which considering his profound impact on the spirit of the PRI during his leadership would also make for a relevant topic of empirical enquiry, particularly on the impacts of individual legitimacy and individual championship (Juravle and Lewis 2009; Mitchell et al. 1997).

More broadly, the motivation for our empirical enquiry into asset owner adoption of the PRI consisted in large part of the role asset owners play as the drivers of the RI market and of economic sustainability in general. We would therefore encourage further research empirically testing this relationship (e.g., the effects of PRI signatory institutional investor ownership of companies on company CSP) to advance our understanding of the process through which the financial system can undergo a transformation towards a more sustainable model.

\section{Conclusion}

The PRI continues to dominate the responsible investing landscape in terms of both its size and scope of activity, which, combined with its explicit interest in mobilizing asset owners' influence in the financial markets to achieve their transition towards a more sustainable model, makes the association's success an important subject of academic inquiry.

Our global quantitative study offers an extended scope and thereby complements existing literature on the determinants of RI adoption by asset owners (Juravle and Lewis 2009; Majoch et al. 2016; Sievänen et al. 2013a, b; Sievänen 2014). Authors such as Sievänen et al. (2013a, b) have previously concluded that the institutional environment of asset owners influences their adoption of RI. For example, they find Nordic or Anglo-Saxon origin to be an explanatory factor, but do not investigate the specific characteristics of these country legal origins in more depth from a theoretical perspective. Responding to Capelle-Blanchard and Monjon's (2012) call for more conceptually and theoretically driven RI research our study investigates the question of asset owner adoption of the PRI using Scott's (1995) three institutional pillars as a theoretical framework in a similar manner to Bengtsson's (2008a, b) discussion of the history of Scandinavian RI in the regulative, normative, and cognitive dimensions. We draw on the extensive body of research looking at the development of socially responsible behavior by different actors from a theoretical perspective (Arjaliès 2010; Baron 2009; Brickson 2007; Campbell 2007; Marquis et al. 2007; Moon and Vogel 2008; Matten and Moon 2008) to inform and guide our application of Scott's tripartite view of institutional theory to the research question. Our results contribute especially to the stream of research studying the institutional and country level characteristics influencing RI adoption by asset owners (Bengtsson 2008a, b; Cox and Schneider 2008; Létourneau 2015; Sandberg et al. 2009; Scholtens and Dam 2007).

We find that normative and cultural-cognitive institutional aspects have the most influence on the probability of asset owner PRI adoption, and to a lesser extent voluntary regulation, while historical levels of mandatory regulation (though not recent activities) decreased the likelihood of asset owner PRI adoption in our sample.

The findings on the normative and cultural-cognitive aspects build our understanding of how cultural, values, and belief factors are major drivers of CSR and RI adoption in general and in the asset owner context in particular (Bengtsson 2008a; Cheah et al. 2011; Francoeur et al. 2017; Hemingway and Maclagan 2004; Scholtens and Sievänen 2013). The symbolic significance of PRI adoption makes it a natural reaction to expectations around an asset owner's behavior (normative institutional aspect) as well as a natural consequence of an alignment with widely held values of the society the asset owner operates within (the cognitive-cultural aspect). Pension funds serving societies displaying more collectivistic and humane attitudes are therefore shown to be more likely to subscribe to a voluntary collaborative initiative with the stated objective of tackling social issues and externalities destroying our collective environmental heritage (Bernhagen and Mitchell 2010). These findings are in line with Majoch et al. (2016) who document the organizational and societal legitimacy benefits of signing the PRI.

By highlighting the differing effects of especially historical levels of voluntary and mandatory ESG regulation on asset owner PRI adoption as markers of the institutional setting, we contribute to the still limited literature on the relationship between regulation and the growth of responsible 
investing (Cox and Schneider 2008; Sandberg et al. 2009; Scholtens 2005; Bengtsson 2008a). In the context of our finding of the influence of the normative institutional setting on asset owners' choice to join the PRI, higher adoption in institutional settings characterized by more historical voluntary regulation could be interpreted as confirming the symbolic and reputation building motivation of institutional investors for PRI adoption, as self-reported by signatories in Majoch et al.'s (2016) study.

Our analysis could also suggest that at an early stage of development of the RI movement, voluntary codes and guidelines foster adoption of RI by helping organizations bridge their knowledge gap and remove uncertainty around implementation. Mandatory regulation meanwhile appears to either discourage (long term) or have no effect (short term) on RI adoption, an effect the authors believe may be due to mandatory requirements taking away some opportunity for reputation building via voluntary initiatives and especially using up organizational resources to focus on compliance, leaving less time and budget to be dedicated to voluntary initiatives such as the PRI. This finding places a heavy emphasis on providing guidance and removing uncertainty as ways of fostering RI growth over more coercive or prescriptive regulatory approaches, in line with other studies such as Juravle and Lewis (2008), Majoch et al. (2016) and Sievänen (2014).

In addition to the various possibilities for future research leading on from this study, such as more detailed investigation of the role of regulation and voluntary guidelines, and the repercussions of asset owner RI adoption in the broader financial and economic system, we also hope that this paper will inspire more research into the PRI and its success, especially in terms of behavior change among its member organizations and their investee companies. Such research may be well deserved, as the PRI continues to solidify its central position in the RI field, with a large amount of collective thinking and action around sustainability in financial markets being concentrated among its growing membership.

Acknowledgements We are deeply grateful for comments from Alexander Bassen, Daniel Beunza, Donato Calace, Fabrizio Ferraro, James Gifford, Jacqueline Humphrey, Erin Levey, Cal Muckley, Carol Padgett, Lorenzo Saa, and seminar participants at Hong Kong Polytechnic University. Yanan Lin provided superb research assistance. We also benefitted significantly from the comments and suggestion of four anonymous referees and Muel Kaptein (the Section Editor). We also would like to thank Marjella Lecourt-Alma and JP Lecourt of
Datamaran for providing us with data on ESG regulations. The views expressed in this paper are not necessarily shared by Auriel Equities, DG FISMA, or Mistra. Authors are listed in alphabetical order. Any remaining errors are our own.

\section{Compliance with Ethical Standards}

Conflicts of interest With regard to potential conflicts of interest, Hoepner and Majoch have consulted the Principles for Responsible Investment in the past but had no commercial relationship since April 2016. Similarly, Hoepner left the PRI's Academic Network steering committee in April 2016. Zhou does and did not have any commercial or advisory relationships to the PRI apart from occasionally attending its Academic Network Conference as many researchers in the field including Hoepner and Majoch do. We are in the process of requesting permission from our data sources to deposit associated data in a data repository.

Open Access This article is distributed under the terms of the Creative Commons Attribution 4.0 International License (http://creativeco mmons.org/licenses/by/4.0/), which permits unrestricted use, distribution, and reproduction in any medium, provided you give appropriate credit to the original author(s) and the source, provide a link to the Creative Commons license, and indicate if changes were made.

\section{Appendix 1: Summary of ESG Regulations Data}

Datamaran's ESG regulations dataset contains over one thousand ESG-related regulations globally and covers 105 ESG topics ranging from Climate Change, Biodiversity, Labor Rights, and Safety to Shareholder Activism and Board Diversity. For each regulation, it clearly records the jurisdiction, commencement year, all related themes and topics, and whether it is mandatory or voluntary. This table shows summary of ESG legislation data used in this study. We first classify ESG legislation by type and ESG theme, and then present it by the accumulative number of laws from 1871 up to 2005. Subsequently, we display the number of newly commenced laws for each year from 2006 to 2010 for the purpose of this study. Columns (1) and (2) report the number $(\%)$ of mandatory and voluntary laws, suggesting that $93.8 \%$ of accumulated regulations up to 2005 are mandatory. Despite that the majority of newly introduced regulations are also mandatory, the percentage of voluntary laws increased from 2006 to 2010. Columns (3), (4), and (5) show the percentage of laws associated with a topic in the realm of the environmental, social, and governance theme, respectively. The top 5 countries with most mandatory legislation up to 2005 are Canada, Germany, Hong Kong, Israel, and United States. The top 5 countries with most voluntarily legislation are France, Italy, Netherlands, United Kingdom, and United States. 


\begin{tabular}{|c|c|c|c|c|c|c|c|}
\hline & & \multicolumn{2}{|l|}{ Type of law } & \multicolumn{3}{|c|}{$\begin{array}{l}\text { Laws associated with topic in E, S or G } \\
\text { theme }\end{array}$} & \multirow[t]{2}{*}{ Total \# } \\
\hline & & \multirow{2}{*}{$\begin{array}{l}\text { Mandatory regula- } \\
\text { tion \# }(\%) \\
\text { (1) }\end{array}$} & \multirow{2}{*}{$\begin{array}{l}\text { Voluntary regula- } \\
\text { tion \# }(\%) \\
\text { (2) }\end{array}$} & \multirow{2}{*}{$\begin{array}{l}\text { Environmen- } \\
\text { tal regulation } \\
\% \\
\text { (3) }\end{array}$} & \multirow{2}{*}{$\begin{array}{l}\text { Social regula- } \\
\text { tion } \% \\
\text { (4) }\end{array}$} & \multirow{2}{*}{$\begin{array}{l}\text { Governance } \\
\text { regulation \% } \\
\text { (5) }\end{array}$} & \\
\hline & & & & & & & (6) \\
\hline $\begin{array}{l}\text { Accumulated regu- } \\
\text { lations }\end{array}$ & Until 2005 & $346(93.80 \%)$ & $23(6.20 \%)$ & 59.1 & 53.1 & 38.9 & 369 \\
\hline \multirow{5}{*}{$\begin{array}{l}\text { Newly introduced } \\
\text { regulations }\end{array}$} & 2006 & $39(88.60 \%)$ & $5(11.40 \%)$ & 79.5 & 65.9 & 45.5 & 44 \\
\hline & 2007 & $20(93.80 \%)$ & $6(6.20 \%)$ & 59.1 & 53.1 & 38.9 & 26 \\
\hline & 2008 & $29(78.40 \%)$ & $8(21.60 \%)$ & 78.4 & 83.8 & 59.5 & 37 \\
\hline & 2009 & $29(85.30 \%)$ & $5(14.70 \%)$ & 91.2 & 73.5 & 52.9 & 34 \\
\hline & 2010 & $25(73.50 \%)$ & $9(26.50 \%)$ & 85.3 & 67.6 & 64.7 & 34 \\
\hline
\end{tabular}

\section{References}

Aguilera, R. V., \& Jackson, G. (2003). The cross-national diversity of corporate governance: Dimensions and determinants. Academy of Management Review, 28(3), 447-465.

Aguilera, R. V., Rupp, D. E., Williams, C. A., \& Ganapathi, J. (2007). Putting the $\mathrm{S}$ back in corporate social responsibility: A multilevel theory of social change in organizations. Academy of Management Review, 32(3), 836-863.

Alandejani, M., Kutan, A. M., \& Samargandi, N. (2017). Do islamic banks fail more than conventional banks? Journal of International Financial Markets, Institutions and Money, 50, 135-155.

Allik, J., \& Realo, A. (2004). Individualism-collectivism and social capital. Journal of Cross-Cultural Psychology, 35(1), 29-49.

Arjaliès, D. L. (2010). A social movement perspective on finance: How socially responsible investment mattered. Journal of business ethics, 92(1), 57-78.

Anderson, B. (2006). Imagined communities: Reflections on the origin and spread of nationalism. London, New York: Verso Books.

Barnett, M. L. (2007). Stakeholder influence capacity and the variability of financial returns to corporate social responsibility. Academy of Management Review, 32(3), 794-816.

Baron, D. P. (2009). A positive theory of moral management, social pressure, and corporate social performance. Journal of Economics \& Management Strategy, 18(1), 7-43.

Bear, S., Rahman, N., \& Post, C. (2010). The impact of board diversity and gender composition on corporate social responsibility and firm reputation. Journal of Business Ethics, 97(2), 207-221. https://doi.org/10.1007/s10551-010-0505-2.

Bengtsson, E. (2008a). A history of Scandinavian socially responsible investing. Journal of Business Ethics, 82(4), 969-983.

Bengtsson, E. (2008b). Socially responsible investing in Scandinavia: A comparative analysis. Sustainable Development, 16(3), 155-168.

Bennie, L., Bernhagen, P., \& Mitchell, N. J. (2007). The logic of transnational action: The good corporation and the Global Compact. Political Studies, 55(4), 733-753.

Bernhagen, P., \& Mitchell, N. J. (2010). The private provision of public goods: Corporate commitments and the United Nations Global Compact. International Studies Quarterly, 54(4), 1175-1187.

Bernhagen, P., Mitchell, N. J., \& Thissen-Smits, M. (2013). Corporate citizens and the un Global Compact: Explaining cross-national variations in turnout. Business and Politics, 15(1), 63-85. https ://doi.org/10.1515/bap-2012-0046.
Boulouta, I. (2013). Hidden connections: The link between board gender diversity and corporate social performance. Journal of Business Ethics, 113(2), 185-197.

Brickson, S. L. (2007). Organizational identity orientation: The genesis of the role of the firm and distinct forms of social value. Academy of Management Review, 32(3), 864-888.

Busch, T., Bauer, R., \& Orlitzky, M. (2016). Sustainable development and financial markets old paths and new avenues. Business \& Society, 55(3), 303-329.

Campbell, J. L. (2006). Institutional analysis and the paradox of corporate social responsibility. American Behavioral Scientist, 49(7), 925-938.

Campbell, J. L. (2007). Why would corporations behave in socially responsible ways? An institutional theory of corporate social responsibility. Academy of Management Review, 32(3), 946-967.

Capelle-Blancard, G. \& Monjon, S. (2012). Trends in the literature on socially responsible investment: looking for the keys under the lamppost. Business Ethics: a European Review, 21, 239-250.

Carbon Disclosure Project. (2017). The carbon majors database. CDP Carbon Majors Report 2017. Retrieved July 8, 2018 from https ://b8f65cb373b1b7b15feb-c70d8ead6ced550b4d987d7c03fcdd 1d.ssl.cf3.rackedn.com/cms/reports/documents/000/002/327/ original/Carbon-Majors-Report-2017.pdf?1499691240.

Cetindamar, D. (2007). Corporate social responsibility practices and environmentally responsible behavior: The case of the United Nations Global Compact. Journal of Business Ethics, 76(2), 163-176.

Cheah, E.-T., Jamali, D., Johnson, J. E. V., \& Sung, M.-C. (2011). Drivers of corporate social responsibility attitudes: The demography of socially responsible investors. British Journal of Management, 22, 305-323. https://doi.org/10.1111/j.1467-8551.2011.00744.x.

Clark, G., \& Hebb, T. (2004). Pension fund corporate engagement: The fifth stage of capitalism. Relations industrielles/industrial relations, 59(1), 142-171.

Clark, G. L., \& Knight, E. R. (2011). Temptation and the virtues of long-term commitment: The governance of sovereign wealth fund investment. Asian Journal of International Law, 1(02), 321-348.

Clark, G. L., \& Monk, A. H. (2010). The legitimacy and governance of Norway's sovereign wealth fund: The ethics of global investment. Environment and Planning A, 42(7), 1723-1738.

Clark, G. L., Hebb, T., \& Wojcik, D. (2007). Institutional investors and the language of finance: The global metrics of market performance. Globalisation of Accounting Standards, pp. 15-33. 
Cleves, M., Gould, W. W., Gutierrez, R. G., \& Marchenko, Y. (2010). An introduction to survival analysis using Stata. College Station, TX: Stata Press Books.

Clowes, M. J. (2000). The Money Flood: How Pension Funds Revolutionized Investing. Wiley Investments.

Cox, D. R. (1972). Regression models and life-tables (with discussion). Journal of the Royal Statistical Society, 34, 187-220.

Cox, P., \& Schneider, M. (2008). Is corporate social performance a criterion in the overseas investment strategy of US pension funds?. An Empirical Examination: Business \& Society.

Deeds, D. L., Mang, P. Y., \& Frandsen, M. L. (2004). The influence of firms' and industries' legitimacy on the flow of capital into high-technology ventures. Strategic Organization, 2(1), 9-34.

Della Croce, R., Stewart, F., \& Yermo, J. (2011). Promoting longerterm investment by institutional investors: Selected issues and policies. OECD Journal: Financial Market Trends, 1, 1-20.

Dent, G. W. (2010). The essential unity of shareholders and the myth of investor short-termism. 35 Delaware Journal of Corporate Law 97 (2010); Case Legal Studies Research Paper No. 09-22.

Dhaliwal, D. S., Li, O. Z., Tsang, A., \& Yang, Y. G. (2011). Voluntary nonfinancial disclosure and the cost of equity capital: The initiation of corporate social responsibility reporting. Accounting Review, 86(1), 59-100.

DiMaggio, P. P., \& Powell, W. W. (1983). The iron cage revisited: Institutional isomorphism and collective rationality in organizational fields. American Sociological Review, 48, 147-160.

Dimson, E., Karakaş, O. \& Li, X. (2018). Coordinated engagements. SHoF-MFS Conference on Sustainable Finance Paper.

Dowling, J., \& Pfeffer, J. (1975). Organizational legitimacy: Social values and organizational behavior. Pacific Sociological Review, 18(1), 122-136.

Dumas, C., \& Louche, C. (2011). Mimetic processes in responsible investment mainstreaming. Proceedings of the International Association for Business and Society, 22, 234-245.

Eccles, N. S. (2010). UN principles for responsible investment signatories and the anti-apartheid SRI movement: A thought experiment. Journal of Business Ethics, 95(3), 415-424.

Espenlaub, S., Goyal, A., \& Mohamed, A. (2016a). Impact of legal institutions on IPO survival: A global perspective. Journal of Financial Stability, 25, 98-112.

Espenlaub, S., Khurshed, A., \& Mohamed, A. (2012). IPO survival in a reputational market. Journal of Business Finance \& Accounting, 39(3-4), 427-463.

Espenlaub, S., Khurshed, A., Mohamed, A., \& Saadouni, B. (2016b). Committed anchor investment and IPO survival: The roles of cornerstone and strategic investors. Journal of Corporate Finance, 41, 139-155.

European SRI study. (2010). Retrieved January 1, 2018 from http:// www.eurosif.org/sri-study-2010/.

Eurosif Study. (2016). Retrieved January 1, 2018 from http://www. eurosif.org/wp-content/uploads/2016//11/SRI-study-2016-HR. pdf.

Francoeur, C., Labelle, R., Balti, S. et al. (2017). To what extent do gender diverse boards enhance corporate social performance? Journal of Business Ethics, 1-15.

George, B., Seals, S., \& Aban, I. (2014). Survival analysis and regression models. Journal of Nuclear Cardiology, 21(4), 686-694. https://doi.org/10.1007/s12350-014-9908-2.

Gjessing, O. P. K., \& Syse, H. (2007). Norwegian petroleum wealth and universal ownership. Corporate Governance: An International Review, 15(3), 427-437. https://doi.org/10.111 1/j.1467-8683.2007.00576.x.

Gond, J.-P., Kang, N., \& Moon, J. (2011). The government of selfregulation: On the comparative dynamics of corporate social responsibility. Economy and Society, 40(4), 640-671.
GSIA. (2016). Global sustainable investment review. http://www. gsi-alliance.org/wp-content/uploads/2017/03/GSIR_Revie w2016.F.pdf.

Guyatt, D. (2005). Meeting objectives and resisting conventions: A focus on institutional investors and long-term responsible investing. Corporate Governance: The international Journal of Business in Society, 5(3), 139-150.

Hafsi, T., \& Turgut, G. (2013). Boardroom diversity and its effect on social performance: Conceptualization and empirical evidence. Journal of Business Ethics, 112(3), 463-479.

Haigh, M., \& Hazelton, J. (2004). Financial markets: A tool for social responsibility? Journal of Business Ethics, 52(1), 59-71.

Harjoto, M. A., \& Jo, H. (2011). Corporate governance and CSR nexus. Journal of Business Ethics, 100(1), 45-67. https://doi. org/10.1007/s10551-011-0772-6.

Hart, S. M. (2010). Self-regulation, corporate social responsibility, and the business case: Do they work in achieving workplace equality and safety? Journal of Business Ethics, 92(4), 585-600.

Haufler, V. (2013). A public role for the private sector: Industry selfregulation in a global economy. Carnegie Endowment.

Hawley, J. P., \& Williams, A. T. (2000). The rise of fiduciary capitalism: How institutional investors can make corporate America more democratic. Philadelphia, PA: University of Pennsylvania Press.

Hawley, J., \& Williams, A. (2007). Universal owners: Challenges and opportunities. Corporate Governance: An International Review, $15(3), 415-420$.

Hebb, T. (2006). The economic inefficiency of secrecy: Pension fund investors' corporate transparency concerns. Journal of Business Ethics, 63(4), 385-405. https://doi.org/10.1007/s1055 1-005-3968-9.

Hemingway, C. A., \& Maclagan, P. W. (2004). Managers' personal values as drivers of corporate social responsibility. Journal of Business Ethics, 50(1), 33-44.

Hockerts, K., \& Moir, L. (2004). Communicating corporate responsibility to investors: The changing role of the investor relations function. Journal of Business Ethics, 52(1), 85-98. https://doi. org/10.1023/b:busi.0000033109.35980.16.

Hoepner, A.G., \& Schopohl, L. (2018a). On the price of morals in markets: An empirical study of the Swedish AP-Funds and the Norwegian Government Pension Fund. Journal of Business Ethics, $1-28$.

Hoepner, A.G., \& Schopohl, L. (2018b). State pension funds and corporate social responsibility: Do political dimensions influence investment decisions? SSRN working paper.

Hofstede, G. (1980). Culture and organizations. International Studies of Management \& Organization, 10(4), 15-41.

Hong, H., \& Kostovetsky, L. (2012). Red and blue investing: Values and finance. Journal of Financial Economics, 103(1), 1-19.

Hosmer, D. W., \& Lemeshow, S. (2008). Applied survival analysis: Regression modelling of time to event data. European Orthodontic Society, 681, 561-562.

House, R. J., Hanges, P. J., Javidan, M., Dorfman, P. W., \& Gupta, V. (2004). Culture, leadership, and organizations: The GLOBE study of 62 societies. London: Sage Publications.

Hughes, J. S., Liu, J., \& Liu, J. (2007). Information asymmetry, diversification, and cost of capital. Accounting Review, 82(3), 705-729.

Inglehart, R. (1997). Modernization and postmodernization: Cultural, economic, and political change in 43 societies (Vol. 19). Cambridge: Cambridge Univ Press.

Ioannou, I., \& Serafeim, G. (2012). What drives corporate social performance? The role of nation-level institutions. Journal of International Business Studies, 43(9), 834-864.

Janney, J. J., Dess, G., \& Forlani, V. (2009). Glass houses? Market reactions to firms joining the UN global compact. Journal of Business Ethics, 90(3), 407-423. 
Jemel-Fornetty, H., Louche, C., \& Bourghelle, D. (2011). Changing the dominant convention: The role of emerging initiatives in mainstreaming ESG. In Finance and sustainability: towards a new paradigm? A post-crisis agenda (pp. 85-117). Emerald Group Publishing Limited.

Juravle, C., \& Lewis, A. (2008). Identifying impediments to SRI in Europe: A review of the practitioner and academic literature. Business Ethics: A European Review, 17(3), 285-310. https:// doi.org/10.1111/j.1467-8608.2008.00536.x.

Juravle, C., \& Lewis, A. (2009). The role of championship in the mainstreaming of sustainable investment (SI) what can we learn from SI pioneers in the United Kingdom? Organization \& Environment, 22(1), 75-98.

Kell, G. (2013). 12 years later reflections on the growth of the UN global compact. Business \& Society, 52(1), 31-52.

Kiernan, M. J. (2007). Universal owners and ESG: Leaving money on the table? Corporate Governance: An International Review, 15(3), 478-485.

Knudsen, J. S. (2011). Company delistings from the UN global compact: Limited business demand or domestic governance failure? Journal of Business Ethics, 103(3), 331-349.

Kreander, N. (2002). The performance and rationale of European ethical funds: An ethical perspective. Ph.D. thesis, University of Glasgow.

Kreander, N., McPhail, K., \& Molyneaux, D. (2004). God's fund managers: A critical study of stock market investment practices of the Church of England and UK Methodists. Accounting, Auditing \& Accountability Journal, 17(3), 408-441.

Lambert, R., Leuz, C., \& Verrecchia, R. E. (2007). Accounting information, disclosure, and the cost of capital. Journal of Accounting Research, 45(2), 385-420.

Létourneau, H. (2015). The responsible investment practices of the world's largest government-sponsored investment funds. In The Routledge handbook of responsible investment.

Leuz, C., \& Schrand, C. (2009). Disclosure and the cost of capital: Evidence from firms' responses to the Enron Shock. NBER Working Paper No. 14897.

Louche, C. (2004). Ethical investment: Processes and mechanisms of institutionalisation in the Netherlands 1990-2002. Doctoral dissertation, Bestuurskunde; Public Administration.

Louche, C., Arenas, D., \& Van Cranenburgh, K. C. (2012). From preaching to investing: Attitudes of religious organisations towards responsible investment. Journal of Business Ethics, 110(3), 301-320.

Lydenberg, S. (2007). Universal investors and socially responsible investors: A tale of emerging affinities. Corporate Governance: An International Review, 15(3), 467-477. https://doi.org/10.11 11/j.1467-8683.2007.00579.x.

Mackey, A., Mackey, T. B., \& Barney, J. B. (2007). Corporate social responsibility and firm performance: Investor preferences and corporate strategies. Academy of Management Review, 32(3), $817-835$.

Majoch, A., Hoepner, A. G. F., \& Hebb, T. (2016). Sources of stakeholder salience in the responsible investment movement: Why do investors sign the principles for responsible investment? Journal of Business Ethics. https://doi.org/10.1007/s10551-016-3057-2.

Marquis, C., Glynn, M., \& Davis, G. (2007). Community isomorphism and corporate social action. Academy of Management Review, 32(3), 925-940.

Matten, D., \& Moon, J. (2008). "Implicit" and "explicit" CSR: A conceptual framework for a comparative understanding of corporate social responsibility. Academy of Management Review, 33(2), 404-424.

McQuail, D. (1985). Sociology of mass communication. Annual Review of Sociology, 11(1), 93-111.
McWilliams, A., \& Siegel, D. (2001). Corporate social responsibility: A theory of the firm perspective. Academy of Management Review, 26(1), 117-127.

Melnyk, S. A., Pagell, M., Jorae, G., \& Sharpe, A. S. (1995). Applying survival analysis to operations management: Analyzing the differences in donor classes in the blood donation process. Journal of Operations Management, 13(4), 339-356. https://doi. org/10.1016/0272-6963(95)00031-3.

Meyer, J. W., \& Rowan, B. (1977). Institutionalized organizations: Formal structure as myth and ceremony. American Journal of Sociology, 83(2), 340-363.

Mitchell, R. K., Agle, B. R., \& Wood, D. J. (1997). Toward a theory of stakeholder identification and salience: Defining the principle of who and what really counts. Academy of Management Review, 22(4), 853-886.

Mollet, J. C., \& Ziegler, A. (2014). Socially responsible investing and stock performance: New empirical evidence for the US and European stock markets. Review of Financial Economics, 23(4), 208-216.

Monks, R. A. (2001). The new global investors: How shareowners can unlock sustainable prosperity worldwide. Mankato: Capstone.

Mooij, S. (2017). Asset Owners and the diffusion of responsible investment. What Explains the low rate of adoption? SSRN. https:// ssrn.com/abstract $=3011287$.

Moon, J. (2007). The contribution of corporate social responsibility to sustainable development. Sustainable Development, 15, 296-306.

Moon, J., \& Vogel, D. (2008). Corporate responsibility, governance, and civil society. In A. Crane, et al. (Eds.), The Oxford handbook of corporate social responsibility (pp. 303-323). Oxford: Oxford University Press.

Pappas, V., Ongena, S., Izzeldin, M., \& Fuertes, A. M. (2017). A survival analysis of Islamic and conventional banks. Journal of Financial Services Research, 51(2), 221-256.

Perez-Batres, L. A., Doh, J. P., Miller, V. V., \& Pisani, M. J. (2012). Stakeholder pressures as determinants of CSR strategic choice: Why do firms choose symbolic versus substantive self-regulatory codes of conduct?. Journal of business ethics, 110(2), 157-172.

Pollock, T. G., \& Rindova, V. P. (2003). Media legitimation effects in the market for initial public offerings. Academy of Management Journal, 46(5), 631-642.

PRI. (2016a). How asset owners can drive responsible investment. London: PRI Association.

PRI. (2016b). Global guide to responsible investing regulation. London: PRI Association.

PRI. (2017). PRI reporting framework 2018: Overview and guidance. London: PRI Association.

PRI. (2018a). Retrieved January 10, 2018 from http://www.unpri.org.

PRI. (2018b). Retrieved June 8, 2018 from http://annualreport.unpri .org/data-snapshot.html.

PRI. (2018c). Retrieved June 8, 2018 from https://www.unpri.org/ Uploads/n/1/1/PRI-Global-growth-2006-2018.xlsx.

Rasche, A. (2009). Toward a model to compare and analyze accountability standards: The case of the UN Global Compact. Corporate Social Responsibility and Environmental Management, 16(4), 192-205.

Rasche, A., \& Waddock, S. (2014). Global sustainability governance and the UN Global Compact: A rejoinder to critics. Journal of Business Ethics, 122(2), 209-216. https://doi.org/10.1007/s1055 1-014-2216-6.

Renneboog, L., Ter Horst, J., \& Zhang, C. (2008). Socially responsible investments: Institutional aspects, performance, and investor behavior. Journal of Banking \& Finance, 32(9), 1723-1742.

Resick, C. J., Hanges, P. J., Dickson, M. W., \& Mitchelson, J. K. (2006). A cross-cultural examination of the endorsement of ethical leadership. Journal of Business Ethics, 63(4), 345-359. 
Royal Bank of Canada. (2018). Responsible investing: Charting a sustainable advantage. http://www.rbcgam.com/corporate-gover nance-and-responsible-investment/pdf/esg-executive-summa ry.PDF.

Sandberg, J. (2010). Socially responsible investment and fiduciary duty: Putting the freshfields report into perspective. Journal of Business Ethics, 101(1), 143-162.

Sandberg, J. (2013). (Re-)interpreting fiduciary duty to justify socially responsible investment for pension funds? Corporate Governance: An International Review, 21(5), 436-446. https://doi. org/10.1111/corg.12028.

Sandberg, J., Juravle, C., Hedesström, T. M., \& Hamilton, I. (2009). The heterogeneity of socially responsible investment. Journal of Business Ethics, 87(4), 519-533.

Scholtens, B. (2005). What drives socially responsible investment? The case of the Netherlands. Sustainable Development, 13(2), 129-137. https://doi.org/10.1002/sd.252.

Scholtens, B. (2006). Finance as a driver of corporate social responsibility. Journal of Business Ethics, 68(1), 19-33. https://doi. org/10.1007/s10551-006-9037-1.

Scholtens, B., \& Dam, L. (2007). Cultural values and international differences in business ethics. Journal of Business Ethics, 75(3), 273-284.

Scholtens, B., \& Sievänen, R. (2013). Drivers of socially responsible investing: A case study of four Nordic countries. Journal of Business Ethics, 115(3), 605-616.

Schwartz, S. H. (1994). Are there universal aspects in the structure and contents of human values? Journal of Social Issues, 50(4), $19-45$.

Scott, W. R. (1995). Institutions and organizations. Foundations for organizational science. London: A Sage Publication Series.

Scott, W. R., \& Christensen, S. (1995). The institutional construction of organizations: International and longitudinal studies. Thousand Oaks, California: Sage Publications.

Sethi, S. P., \& Schepers, D. H. (2013). Developing a framework for critiquing multi-stakeholder codes of conduct. In Proceedings of the International Association for Business and Society (Vol. 24, pp. 226-239). https://doi.org/10.5840/iabsproc20132424.

Sethi, S. P., \& Schepers, D. H. (2014). United Nations global compact: The promise-performance gap. Journal of Business Ethics, 122(2), 193-208.

Sethi, S. P. (2005). Investing in socially responsible companies is a must for public pension funds: Because there is no better alternative. Journal of Business Ethics, 56(2), 99-129.

Sievänen, R. (2014). Practicalities bottleneck to pension fund responsible investment? Business Ethics: A European Review, 23(3), 309-326. https://doi.org/10.1111/beer.12048.

Sievänen, R., Rita, H., \& Scholtens, B. (2013a). The drivers of responsible investment: The case of European pension funds. Journal of Business Ethics, 117(1), 137-151.

Sievänen, R., Sumelius, J., Islam, K. M. Z., \& Sell, M. (2013b). From struggle in responsible investment to potential to improve global environmental governance through UN PRI. International
Environmental Agreements: Politics, Law and Economics, 13(2), 197-217. https://doi.org/10.1007/s10784-012-9188-8.

Sparkes, R. (1995). The ethical investor. New York: HarperCollins.

Sparkes, R. (2002). Socially responsible investment: A global revolution. Chichester: Wiley.

Sparkes, R., \& Cowton, C. J. (2004). The maturing of socially responsible investment: A review of the developing link with corporate social responsibility. Journal of Business Ethics, 52(1), 45-57.

Stiglitz, J. E., Vieira, L., Hatwich, F., Arévalo, V., Andino, M., Grijalva, J., et al. (2000). Economics of the public sector: ISNAR, La Haya (Países Bajos). San José: IICA.

Suchman, M. C. (1995). Managing legitimacy: Strategic and institutional approaches. Academy of Management Review, 20(3), 571-610.

Thamotheram, R., \& Wildsmith, H. (2006). Putting the universal owner hypothesis into action: Why large retirement funds should want to collectively increase overall market returns and what they can do about It. In: Delegate Handbook Corporate Governance $8 \mathrm{c}$ Responsible Investment.

Thamotheram, R., \& Wildsmith, H. (2007). Increasing long-term market returns: realising the potential of collective pension fund action. Corporate Governance: An International Review, 15(3), 438-454. https://doi.org/10.1111/j.1467-8683.2007.00577.x.

The Guardian (2015). Revealed: Gates Foundation's \$1.4bn in fossil fuel investments. https://www.theguardian.com/environmen t/2015/mar/19/gates-foundation-has-14bn-in-fossil-fuels-inves tments-guardian-analysis.

United Nations. (2018). The sustainable development goals report 2018. Retrieved July 8, 2018 from https://unstats.un.org/sdgs/ report/2018/overview.

Vietols, S. (2011). European pension funds and socially responsible investment. Transfer: European Review of Labor and Research, 17(1), 29-41.

Voegtlin, C., \& Pless, N. M. (2014). Global governance: CSR and the role of the UN Global Compact. Journal of Business Ethics, 122(2), 179-191.

Vogel, D. (2010). The private regulation of global corporate conduct: Achievements and limitations. Business \& Society, 49(1), 68-87.

Waddock, S. (2008). Building a new institutional infrastructure for corporate responsibility. The Academy of Management Perspectives, 22(3), 87-108.

Waldman, D. A., \& Siegel, D. (2008). Defining the socially responsible leader. The Leadership Quarterly, 19(1), 117-131.

Williams, O. F. (2004). The UN Global Compact: The challenge and the promise. Business Ethics Quarterly, 14(04), 755-774.

World Resource Institute. (2016). Navigating the sustainable investment landscape. Retrieved July 8, 2018 from http://www.wri. org/publication/sustainable-investment-landscape.

Publisher's Note Springer Nature remains neutral with regard to jurisdictional claims in published maps and institutional affiliations. 